\title{
Current Scenario of Hepatitis B and Its Treatment in India
}

\author{
Gautam Ray* \\ Gastroenterology Unit, Department of Medicine, B.R.Singh Hospital, Kolkata, India
}

\begin{abstract}
Hepatitis B is a significant public health problem in India, yet disease awareness is very low among the general population. The disease is mostly acquired horizontally, but the role of vertical transmission should not be underestimated. In spite of the fact that the majority of cases are e negative disease, most patients present in the advanced stage and even with hepatocellular carcinoma, the leading cause of which is hepatitis B. High-risk groups (especially tribals) also harbour significant disease burden and have a high prevalence of occult infection, supporting the potential of unknowingly spreading the disease. Findings on the relation of genotypes with disease severity or drug action have been conflicting. Though recently, oral antivirals with high genetic barrier to resistance have shown good viral suppression in the long term, e and s seroconversion is poor and relapse is universal upon therapy discontinuation. As no cure is possible with the currently available therapy, the target is long-term viral suppression by prolonged administration of oral antivirals; unfortunately, this leads to poor treatment adherence, which along with the high cost of therapy results in disease progression and spread of infection. At present, therefore, emphasis should be put on health education of the general and high-risk populations, along with health care workers to increase knowledge on such preventive measures as avoiding unsafe injection practices, high-risk sex, performing unnecessary injection and blood transfusion and providing proper screening of blood products; these efforts should be combined with intensive screening and aggressive vaccination programs, especially in high-risk groups and areas of high endemicity. Vaccination strategies are still below par and logistics should be developed for wider coverage; in addition, further research should be carried out on the efficacy and mode of usage for different types of vaccine.
\end{abstract}

Keywords: Hepatitis B; Epidemiology; Clinical; Prevention; Treatment; India. Abbreviations: AASLD, American Association for Study of Liver Diseases; ADV, adefovir; ALT, alanine aminotransferase; antiHBC, antibody to core antigen; antiHBe, HBe antibody; antiHBs, antibody to HBsAg; APASL, Asia Pacific Association for Study of Liver; APRI, aspartate aminotransferase to platelet ratio index; bcp, basal core promoter; CHB, chronic hepatitis B; CLD, chronic liver disease; CTP, Child-Turcotte-Pugh; e-ve, HBeAg negativity; e+ve, HBeAg positivity; EASL, European Association for Study of Liver; EOTR, end of treatment response; ETV, entecavir; HAART, highly active antiretroviral therapy; HBIg, hepatitis B immunoglobulin; HBV, hepatitis B virus; HCC, hepatocellular carcinoma; HCV, hepatitis C virus; HIV, human immunodeficiency virus; IFN, interferon; LAM, lamivudine; LdT, telbivudine; LT, liver transplantation; MELD, model for end-stage liver disease; $\mathrm{NA}$, nucleos(t)ide analogues; $\mathrm{pc}$, precore; pegIFN, pegylated interferon; RCT, randomised controlled trials; SVR, sustained viral response; TDF, tenofovir; ULN, upper limit of normal.

Received: 18 March 2017; Revised: 18 May 2017; Accepted: 3 June 2017

*Correspondence to: Gautam Ray, B.R.Singh Hospital, Sealdah, Kolkata 700014, West Bengal, India. Tel: +91-3323504075, Fax: +91-323507003, E-mail: gautam1910@yahoo.com
Citation of this article: Ray G. Current scenario of hepatitis B and its treatment in India. J Clin Transl Hepatol 2017;5(3): 277-296. doi: 10.14218/JCTH.2017.00024.

\section{Introduction}

Hepatitis B is a common disease all over the world, and countries have been divided into three groups (high, intermediate and low) according to its endemicity. It is estimated that about 200 cores of the world's population have been exposed to the hepatitis B virus (HBV), of whom 350 million harbour it chronically. India falls in the intermediate endemicity zone (prevalence of $2-7 \%$, with an average of $4 \%$ ), with a disease burden of about 50 million. Pockets of higher endemicity are found in tribal areas where the high burden is maintained through intracaste marriages, tribal customs, illiteracy and poor exposure to health care resources.

In India, chronic hepatitis B (CHB) is acquired predominantly by horizontal transmission in early childhood (mostly from family contacts) and to lesser extent by perinatal transmission. The exact mode of horizontal transmission remains undefined, but it may be due to contact of non-intact skin or mucous membranes with tears, saliva or blood containing HBV-infected secretions or through sharing of toothbrushes. The age of acquisition of HBV is an important determinant of outcome; the earlier the age, the higher the risk of chronicity (e.g., $>90 \%$ in new-borns (vertical transmission), $30 \%$ in children aged $2-5$ years and $<5 \%$ in adults). The other mode is parenteral transmission at any age (i.e. transfusion of infected blood or blood products, intravenous drug use, unsafe therapeutic injections, occupational injuries or nosocomial transmission during healthcare-related procedures such as surgery, haemodialysis and organ transplantation). ${ }^{1}$

The disease passes through three phases in its natural history - (a) immunotolerant phase with e+ve and high DNA load with normal enzymes, (b) immune active phase with surge in enzymes, hepatitis $B$ e antigen ( $\mathrm{HBeAg}$ ) negativity (a state known as e-ve) and clearance of DNA, and (c) inactive carrier phase with development of $\mathrm{HBe}$ antibody (antiHBe), normal enzyme levels and negativity for HBV DNA. A section of inactive carriers may revert back to DNA positivity with e-ve state and develop e-ve hepatitis. Some will remain as occult infection (hepatitis $B$ surface antigen (HBsAg)-negative and $\mathrm{HBeAg}$-negative but DNA-positive). A good number of cases (15-25\%) will progress to $\mathrm{CHB}$, decompensated cirrhosis and hepatocellular carcinoma (HCC). Risk factors for progression are $\mathrm{HBeAg-positivity}$ (the state known as e+v) and high DNA load, among others, and all treatment modalities target e seroconversion and DNA negativity as practically achievable end points. 
Ray G.: Hepatitis B in India

Progression also occurs in e-ve hepatitis due to intermittent flares and in occult infection in immune-active disease but at a slower rate. A recent trend in decrease of HBV as the chief cause of chronic liver disease (CLD) is being observed in India, mostly due to rising incidence of alcohol-related disease; however, HBV infection still remains the leading cause of HCC. Till only a few years back, HBV-related CLD was regarded as a relative contraindication for liver transplantation (LT), but with recent availability of hepatitis B immunoglobulin (HBIg) and potent oral antiviral drugs such cases are being transplanted in India, where LT programmes have taken wing in the last few years.

Prevalence of HBV is also higher than average in high-risk groups like patients with chronic kidney disease, on dialysis, with thalassemia, haemophilia or leukaemias, or those receiving immunosuppressives or cancer chemotherapy. Fortunately, about two-thirds of the disease burden in India is represented by e-ve disease, with low or undetectable viral load which naturally mitigates the disease severity to some extent. However, this ameliorating effect, along with that of vaccination, may be offset by the rising burden of high-risk groups (especially patients on dialysis or with human immunodeficiency virus (HIV), people who are elderly, or those with cancer or on immunosuppressives), who are living longer with their disease. Pregnant women also need screening for HBV to stop perinatal/horizontal transmission.

\section{HBV burden in CLD/HCC}

Alcohol is presently the most common aetiology of CLD in India, and this representation has emerged over a span of the last few years (Fig. 1). ${ }^{2-13}$ Interestingly, this is due to rising alcohol consumption rates and not due to a real decrease in prevalence of HBV infection (which has remained stable over the years ${ }^{3}$ ) nor the effect of vaccination (as the vaccine programme in India on mass basis started only in 2011). However, HBV infection still remains the most common aetiology of HCC all over India. A recent all-India survey revealed that $43 \%$ of HCC cases are HBV-associated; ${ }^{14}$ prevalence among $\mathrm{HCC}$ cases is $42 \%$ in the south, ${ }^{15} 39-69 \%$ in the north ${ }^{16-20}$ and $82 \%$ in the west. ${ }^{21}$

In India, a large number of patients present in the advanced stage of the disease, even with HCC at the first clinical presentation, when curative treatment is not possible. ${ }^{14,22} \mathrm{~A}$ recent series study on LT found that $80 \%$ of HCC in explants was associated with HBV and/or hepatitis $C$ virus $(\mathrm{HCV}) .{ }^{23}$ Primary liver cancer deaths and related years of life lost attributable to hepatitis B was found to be $67 \%$ (population-attributable fraction; real number being 17000) and 297000 in India. ${ }^{24}$ This is despite the fact that the majority of patients are e-ve, which might cause silent and slow progression. E-negative disease has been reported in hospital-based studies to be $52-79 \%$ from the north, ${ }^{25-29} 55-80 \%$ from the east, ${ }^{3,22,30,31} 61 \%$ from the west ${ }^{32}$ and $72-75 \%$ from the south, ${ }^{12,33-35}$ with corresponding figures for e-negative hepatitis as $31-56 \%, 26-70 \%, 40 \%$ and $26-75 \%$ respectively. One community-based study from the east showed community prevalence of e-negative disease to be $90 \%$ and of e-negative hepatitis to be $32 \%{ }^{36}$

\section{Mutants and disease}

E-negative hepatitis results from mutation in the precore (pc) and basal core promoter (bcp) regions of HBV genome.
Such infection results in hepatitis having lower DNA levels compared to e+ve disease and causes disease progression to occur silently to cirrhosis, with intermittent flares (often subclinical). ${ }^{27,32}$ The other common mutation site is the surface gene (surface mutant) which renders the common screening marker HBsAg undetectable by normal assay method; in this manner, the disease is occult but active and with high DNA levels.

The prevalence of pc mutants has been found to be $12-29 \%$ (bcp $15-21 \%{ }^{30,36}$ ) in the east, $15-71 \%$ in the north, ${ }^{25-28}$ $26-40 \%$ in the west ${ }^{5,32}$ and $7.1-30 \%$ in the south. ${ }^{12,33,37} \mathrm{An}$ all-India study ${ }^{38}$ found bcp in $29.3 \%$ and pc in $21.3 \%$, overall being $40 \%$. Surface mutants were found in $10 \%$ in the east, $7.6-10.8 \%$ in the north 25,27 (including $29 \%$ in family contacts $\left.{ }^{39}\right), 3.2 \%$ in the south, ${ }^{34}$ and $18 \%$ in the west. $^{32}$ Such infection is particularly prevalent among highrisk groups (e.g., voluntary blood donors $\left(24 \%{ }^{40}\right)$, tribals $\left(10-19.5 \%^{30,41}\right)$ and other groups $\left(20 \%{ }^{42}\right)$. This high rate is of sinister significance, as it not only results in silent disease progression but also spread of disease unknowingly via donated blood. High prevalence of occult infection has been demonstrated in HCC patients as well. $25,27,43,44$

\section{Genotype and disease $\mathrm{e}^{31,44-65}$}

The most prevalent genotype in India is $D$ followed by $A$, with the exception of east and north eastern India where genotype $\mathrm{C}$ is also high. In the northern half of India there is a gradual trend of increasing genotype $\mathrm{C}$ as one moves eastward, and this rise also represents a recent change ${ }^{66}$ (Fig. 2). Studies have yielded conflicting results on the relation of genotype to severity of liver disease and drug response (Table 1 ). This may be partially related to the relation of genotype to different viral mutations, which can influence the type of liver disease manifested. ${ }^{51,54,61,63}$ Also, the patients might be harbouring different genotypes (in blood and liver tissue) simultaneously, but one could be predominant and thereby be the detectable one, as has been exemplified in (a) liver tissue harbouring genotype $C$ whereas peripheral blood harbours genotype $\mathrm{D}^{64}$ (b) presence of viral reverse transcriptase mutation in treatment-naïve patients (which is genotype related ${ }^{67}$ ) and (c) genotype switch while on therapy. ${ }^{62}$ Genotype may also determine the mode of transmission (horizontal vs. vertical).

\section{Hepatitis B in special populations}

\section{Children}

Rates of HBsAg-positivity are 2.14-2.25\% among children $<5$ years of age and $4.3-7.2 \%$ among the entire paediatric population (up to 12 years of age) attending general outpatient services with non-liver problems ${ }^{68}$ (implying horizontal transmission), whereas it is $6.7 \%$ among those with liver disease. ${ }^{69}$ In another study on CLD of non-viral aetiology, occult infection was found in $9 \%$ (markers in $39.3 \%)^{70}$ Though horizontal transmission appears to be the predominant mode, ${ }^{71}$ there is definite contribution of vertical transmission as well. ${ }^{72,73}$

Treatment with interferon (IFN) gives good results, with $52-60 \%$ sustained viral response (SVR) with HBeAg loss and seroconversion rates of $39-44 \%$ and $20-39 \%$, higher in the horizontal group than in the vertical transmission group. Sequential combination with lamivudine (LAM) yielded better results, with HBsAg loss of $21.4 \%$. Again, however, studies are few and with small patient number. ${ }^{74,75}$ 
Ray G.: Hepatitis B in India

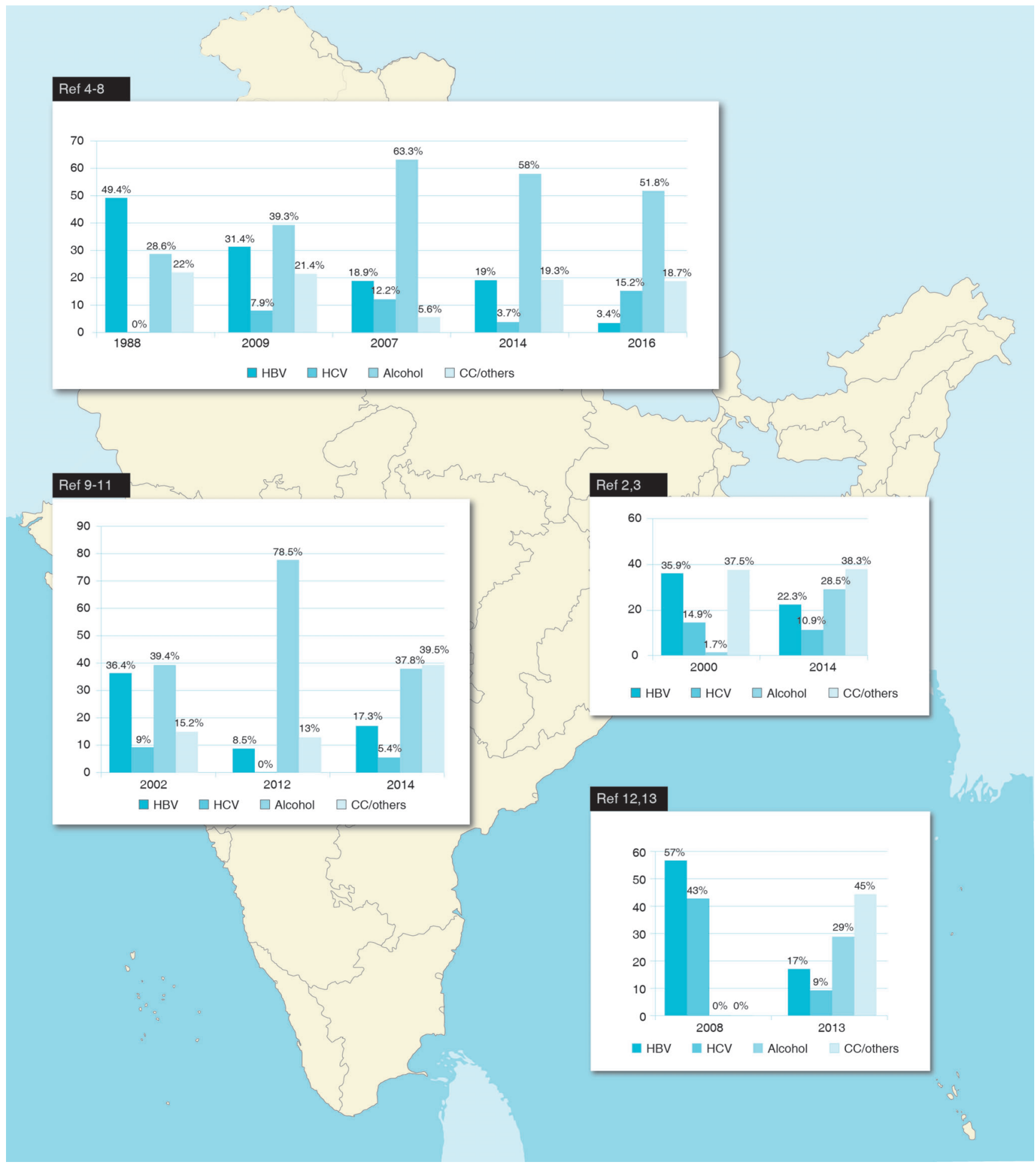

Fig. 1. Trends in aetiology of chronic liver disease in north, west, south and east India.

\section{HIV}

In India, the coinfection rate has been found to be $0.2-8 \%$ in peripheral HIV/sexually transmitted disease clinics and tuberculosis clinics. ${ }^{76}$ In the major metropolis areas, the rates are
$11.3 \%$ in Kolkata, ${ }^{77} 16.7 \%$ in Mumbai, ${ }^{78} 15 \%$ in Hyderabad, $^{79} 9 \%$ in Chennai, ${ }^{80}$ and $5.3 \%$ in Delhi. ${ }^{81}$ Cases are higher with sexually acquired HIV infection compared to parenterally acquired HIV infection. The genotype distribution is similar to that of the general HBV affected population, but 


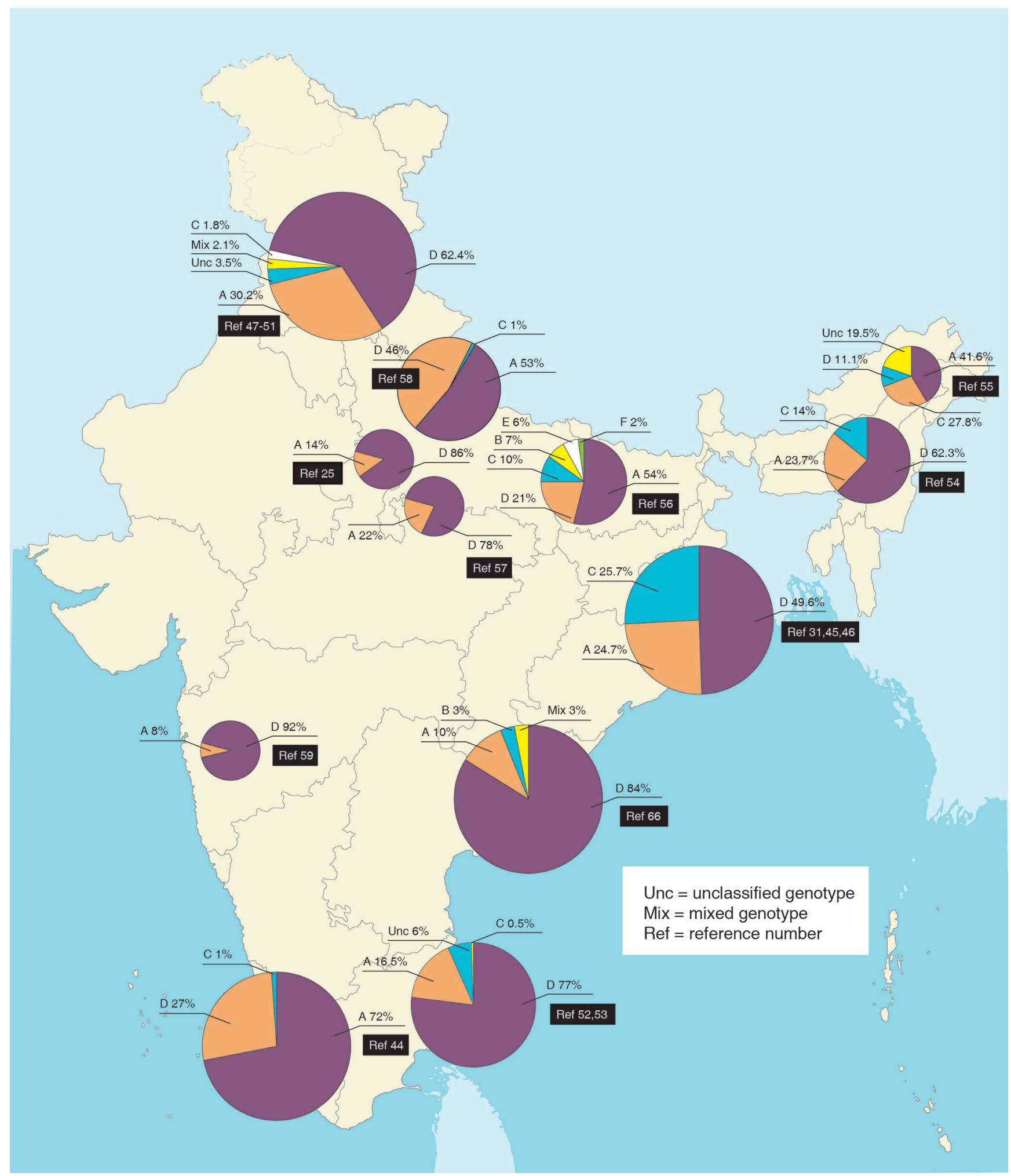

Fig. 2. Genotypic distribution of hepatitis B virus in different parts of India. Data are presented as percentage.

with more e+ve disease ${ }^{77}$ and occult infections in up to $10.7 \% .{ }^{82}$ Long-term treatment with LAM-based highly active antiretroviral therapy (HAART) cause a greater number of mutations ${ }^{83}$ than tenofovir (TDF)-based HAART therapy, which gave better results. ${ }^{84}$ Drug-resistant mutations reportedly occur in $3.8 \% .^{77}$ 
Ray G.: Hepatitis B in India

Table 1. Relation of hepatitis B genotype to disease states or drug effects

\begin{tabular}{|c|c|}
\hline Positive association & Negative association \\
\hline $\begin{array}{l}\text { Precore G1896A mutation was e-ve and genotype D-specific, } \\
\text { but G1862T mutation was e+ve and genotype A-specific }{ }^{63}\end{array}$ & $\begin{array}{l}\text { Disease states (acute hepatitis, chronic hepatitis, } \\
\text { asymptomatic carriers, CLD or HCC), the hepatitis activity } \\
\text { index and fibrosis stage and treatment response }{ }^{50}\end{array}$ \\
\hline $\begin{array}{l}83 \% \text { of G1862T mutations detected in genotype A cases vs, } \\
17 \% \text { in genotype } D^{31}\end{array}$ & Disease severity ${ }^{61}$ \\
\hline $\begin{array}{l}\text { Genotype D was associated with more severe liver disease in } \\
\text { the incidentally-detected group, and was more prevalent in } \\
\text { HCC patients of }<40 \text { years of age compared to the } \\
\text { incidentally-detected group } 47\end{array}$ & Acute, fulminant and incidentally-detected disease ${ }^{59}$ \\
\hline $\begin{array}{l}\text { Genotype } D: A=2: 1 \text { in asymptomatic carriers, chronic } \\
\text { hepatitis and CLD, but } 1: 1 \text { in HCC. Precore G1896A in } 46 \% \\
\text { of genotype D vs. } 25 \% \text { of genotype } A^{51}\end{array}$ & CLD, chronic hepatitis or HCC cases $^{49}$ \\
\hline $\begin{array}{l}\text { Genotype D achieved higher SVR on LAM therapy than did } \\
\text { genotype } A^{48}\end{array}$ & Responders and non-responders to LAM therapy ${ }^{48}$ \\
\hline $\begin{array}{l}\text { In the }>25 \text { year-old age subgroup, genotype } A \text { is more often } \\
\text { associated with CLD than is genotype } D^{58}\end{array}$ & Long-term response to TDF therapy ${ }^{62}$ \\
\hline More genotype A patients had Child class C disease ${ }^{57}$ & LAM response and YMDD mutation ${ }^{86}$ \\
\hline $\begin{array}{l}\text { Genotype } C \text { is associated with higher viral load, e+ve disease } \\
\text { and increased risk of CLD }\end{array}$ & ETV response ${ }^{101}$ \\
\hline \multicolumn{2}{|l|}{$\begin{array}{l}\text { bcp and pc mutations were more frequent in genotype D cases } \\
\text { compared with genotype A cases }\end{array}$} \\
\hline \multicolumn{2}{|l|}{$\begin{array}{l}\text { Genotype D cases showed significantly high acute hepatitis, } \\
\text { whereas genotype C cases showed higher chronic hepatitis }{ }^{60}\end{array}$} \\
\hline \multicolumn{2}{|l|}{ All non-responders to ETV/TDF had genotype $D^{103}$} \\
\hline \multicolumn{2}{|l|}{$\begin{array}{l}\text { Genotype A or mixed genotype cases are more likely to } \\
\text { undergo inter-genotype switch on long-term TDF therapy } \\
\text { compared to genotype D cases }{ }^{62}\end{array}$} \\
\hline $\begin{array}{l}\text { HCC patients infected with genotype A were significantly } \\
\text { younger than those infected with genotype D. Pc mutation } \\
\text { G1862T and bcp mutation } C 1766 \mathrm{~T} / \mathrm{T} 1768 \mathrm{~A} \text { were more } \\
\text { frequent in genotype A cases and significantly associated with } \\
\text { HCC }^{44}\end{array}$ & \\
\hline
\end{tabular}

Abbreviations: LAM, lamivudine; ETV, entecavir; TDF, tenofovir; e+ve, HBeAg-positive; CLD, chronic liver disease; HCC, hepatocellular carcinoma; pc, precore; bcp, basal core promoter.

\section{Blood-borne infections}

Prevalence of HBsAg positivity in chronic kidney disease patients undergoing haemodialysis and renal transplant is $5.2-18.7 \%{ }^{85-88}$ but much higher when combined with detection of antibodies to $\mathrm{HCV}(37.1 \%),{ }^{89}$ depending on duration of therapy. In thalassemia patients, it was $35-69 \%$ in the 1990 s, but is now as low as $2 \% ; 1,90,91$ but, the recent cases include a high rate of occult infection ( $50 \%$ in antibody to core antigen (antiHBc) + and $16 \%$ in both antiHBc and antibody to HBsAg (antiHBs)+ cases $^{92}$ ). Rate in haemophilia patients is $6-9 \%{ }^{91,93}$ and in acute leukaemia patients is $15.9 \% .{ }^{94}$ Voluntary blood donors have a rate of $0.2-4 \%,{ }^{1}$ with high prevalence of occult infection. ${ }^{40}$

\section{Intravenous drug abuse}

The rate of HBsAg positivity was reported earlier as $2.7-10.8 \%$ among intravenous drug users, ${ }^{1}$ but in more recent studies it was reported as $7 \%$ in Chennai, ${ }^{95} 9.7 \%$ in Delhi ${ }^{96}$ and $5.1 \%$ in another region. ${ }^{97}$ In an area reported with highest drug abuse, occult infection was found in $15.9 \% .98$

\section{Tribals}

India has a large tribal population residing in different pockets spread all over the country and prevalence is very high among some (up to $65 \%$ ), including occult infection rate of $10-9.5 \% .^{30,41,99}$ The majority have genotype $D$ infection. ${ }^{100}$ As most infections are acquired early in life, chronicity is high and most cases are asymptomatic. The high burden is maintained through intracaste marriages, close living, tribal customs, illiteracy and poor exposure to health care resources.

In a study of occult HBV infections among different highrisk groups, overall prevalence was found to be $3.2 \%(10 \%$ in hepatitis $\mathrm{C} /$ cryptogenic cirrhosis cases, $7.7 \%$ in HIV cases, $2 \%$ in malignancy cases, $2 \%$ in alcoholic cirrhosis cases, $1.7 \%$ in alcohol dependence case, and none in blood donors and patients with chronic kidney disease). ${ }^{42}$ Thus, in all such high-risk groups, a definite proportion have occult infection, 
Ray G.: Hepatitis B in India

and remain undetectable on routine screening; such infections, however, might manifest in situations of jeopardised immunity or represent an unrecognised source of infection outbreak. There is also a high prevalence of occult infection among family contacts of HBsAg-positive patients. ${ }^{39}$

\section{Pregnancy}

Overall, the seroprevalence of $\mathrm{HBsAg}$ reported in three recent studies that involved screening of 3686, 20104 and 4000 pregnant females ranged from $0.9 \%$ to $1.1 \% ;^{101-103}$ this finding was not different from that in the normal population. HBV reportedly constitutes $25.6 \%$ of liver disease in pregnancy. ${ }^{104}$ Vertical transmission has been found in $45.2 \%$ of cases, ${ }^{103}$ attesting to the imprecise knowledge of HBV transmission dynamics; and, as stated above, the role of perinatal versus horizontal transmission among Indian children needs to be further refined.

\section{Other modes of transmission}

\section{Sexual transmission}

By itself this mode adds little to the chronicity burden (e.g., spouse $0 \%{ }^{3}$ ) but it does represent the predominant mode of coinfection in sexually acquired HIV infection.

\section{Health care workers and unsafe injection practices ${ }^{1}$}

The risk of contracting HBV is four-times greater for health care workers compared to that of the general adult population. While prevalence in the 1990 s was $(2.21-10 \%)$, recent studies show lower prevalence $(0.4-1.4 \%)$, possibly due to better preventive measures and awareness. The highest rates are seen among dentists, physicians, laboratory workers, dialysis workers, cleaning service employees, and nurses.

Annual injection rates in India are considered to be between 4-5 billion and two-thirds are considered unsafe due to inadequate sterilization, use of faulty techniques or unsatisfactory injection waste disposal. The estimated median population-attributable fraction for chronic hepatitis B linked to injections in India is reportedly $46 \%$.

The other high-risk groups in whom HBV may flare up from past infection, carrier state and occult infection are those with diseases being treated with biologics or immunosuppressive medicines (e.g., inflammatory bowel disease, autoimmune disorders, psoriasis, post-organ transplant, cancer chemotherapy, etc.). Presently, there are very limited data on HBV disease in these groups, but their number is rising; moreover, as these individuals live longer with their disease, they are likely to add to the disease burden. Strict vigilance is needed to monitor the status of HBV in such people, as well as the effects of early institution of pre-emptive therapy to prevent flare up.

\section{Initiation and end point of treatment}

The ultimate goal of therapy is global eradication of HBV infection by different strategies of vaccination, treatment and prevention of transmission. Treatment is aimed at prevention of disease progression to end stage and transmission to others, along with improving survival and quality of life for the patients. The best way to achieve this goal is complete cure of HBV by eradicating the covalently closed circular DNA from liver, resulting in complete loss of HBsAg (the ideal end point of therapy also). As this is not possible with the currently available drugs, the next best realistic goal is sustained suppression of HBV replication in both $e+v e$ and $e-v e$ patients, with/without e seroconversion in e+ve patients by long-term therapy. Reducing histological activity lessens the risk of cirrhosis and HCC, particularly in non-cirrhotic patients. Sustained virologic remission when off therapy can also be a satisfactory end point.

The indications for treatment are generally based on the e antigen status, serum alanine aminotransferase (ALT) and DNA levels, and severity of liver disease (assessed clinically or by liver biopsy/non-invasive methods). Guidelines published by various societies (European Association for Study of Liver (EASL), American Association for Study of Liver Diseases (AASLD) and Asia Pacific Association for Study of Liver $($ APASL $))^{105-107}$ regarding initiation and termination of therapy are shown in Tables 2 and 3. For optimal therapy, other factors that need consideration are treatment duration, rapidity of drug action and its adverse effect profile, prevention of drug resistance along with management of viral breakthrough. All guidelines recommend initial treatment with drugs that have high potency and high genetic barrier to resistance (entecavir (ETV), TDF or pegylated (peg) IFN) to minimise the DNA level as quickly as possible, thereby reducing the risk of resistance development.

However, in India, though all first-line approved agents are available, the major hurdle in treatment initiation and maintenance is unaffordability due to high cost of therapy. The cost of oral therapy with nucleos(t)ide analogues (NAs) ranges from 76 to $1707 \mathrm{USD}(\$)$ for $\mathrm{CHB} /$ compensated cirrhosis to 15000 USD for HCC patients, and may be as high as 20000 USD in patients with decompensated cirrhosis. ${ }^{108}$ As patients have to bear the cost of medicines from their own pocket, their preference also needs consideration in deciding therapy. Due to cost constraints, patients either skip/split the dose or discontinue therapy, avoid new prescriptions, delay refills and use generics. This results in inadequate control and increases the risk of resistance/virologic breakthrough.

The other problems are poor follow-up, lack of awareness about the importance of treatment adherence and social obstacles like lack of screening programs, social stigma, and limited resource allocation (i.e. laboratories, staff, health care practitioners and reimbursement of drugs/tests). Thus, although a guideline for HBV therapy in India formulated by Indian experts was published, ${ }^{109}$ the adherence to it by patients and physicians is uncertain. This leads to dismal efficacy results on intention-to-treat analysis and uncertain perprotocol analysis results in drug trials. ${ }^{110}$

\section{Drug therapy}

Different drugs for treatment of $\mathrm{CHB}$ and the years of their availability is summarized (1990 - Interferon alpha; 1998 Lamivudine; 2002 - Adefovir; 2005 - Pegylated interferon \& Entecavir; 2006 - Telbivudine; 2008 - Tenofovir). These drugs can be used either singly or in combination, according to indications. The most popular therapy presently is ETV or TDF administered as monotherapy. Combination therapy is still controversial, and if it is to be used then it should be administered as either two NAs simultaneously/add-on or as an IFN and a NA simultaneously/sequentially. The logic of using NA combination is that two agents acting through 
Ray G.: Hepatitis B in India

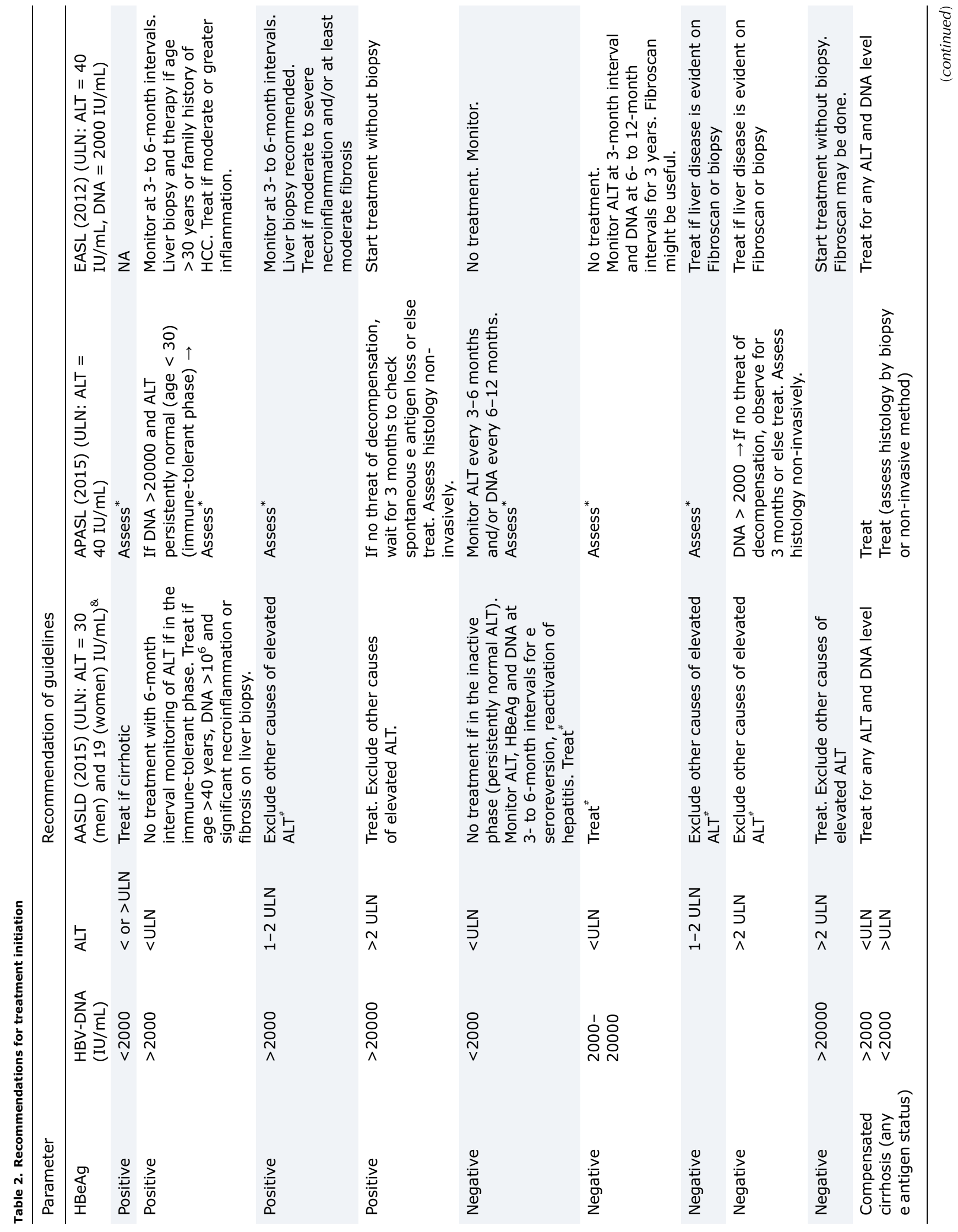


Ray G.: Hepatitis B in India

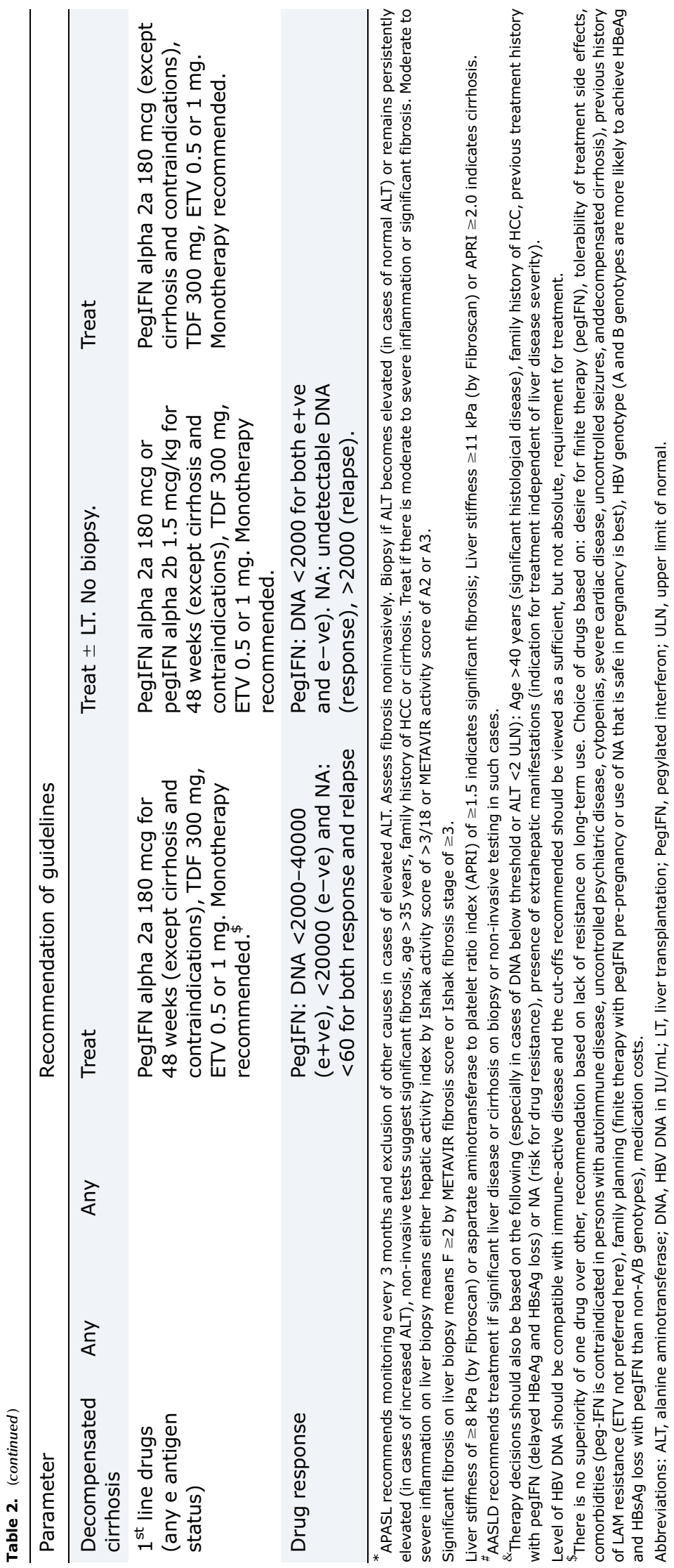




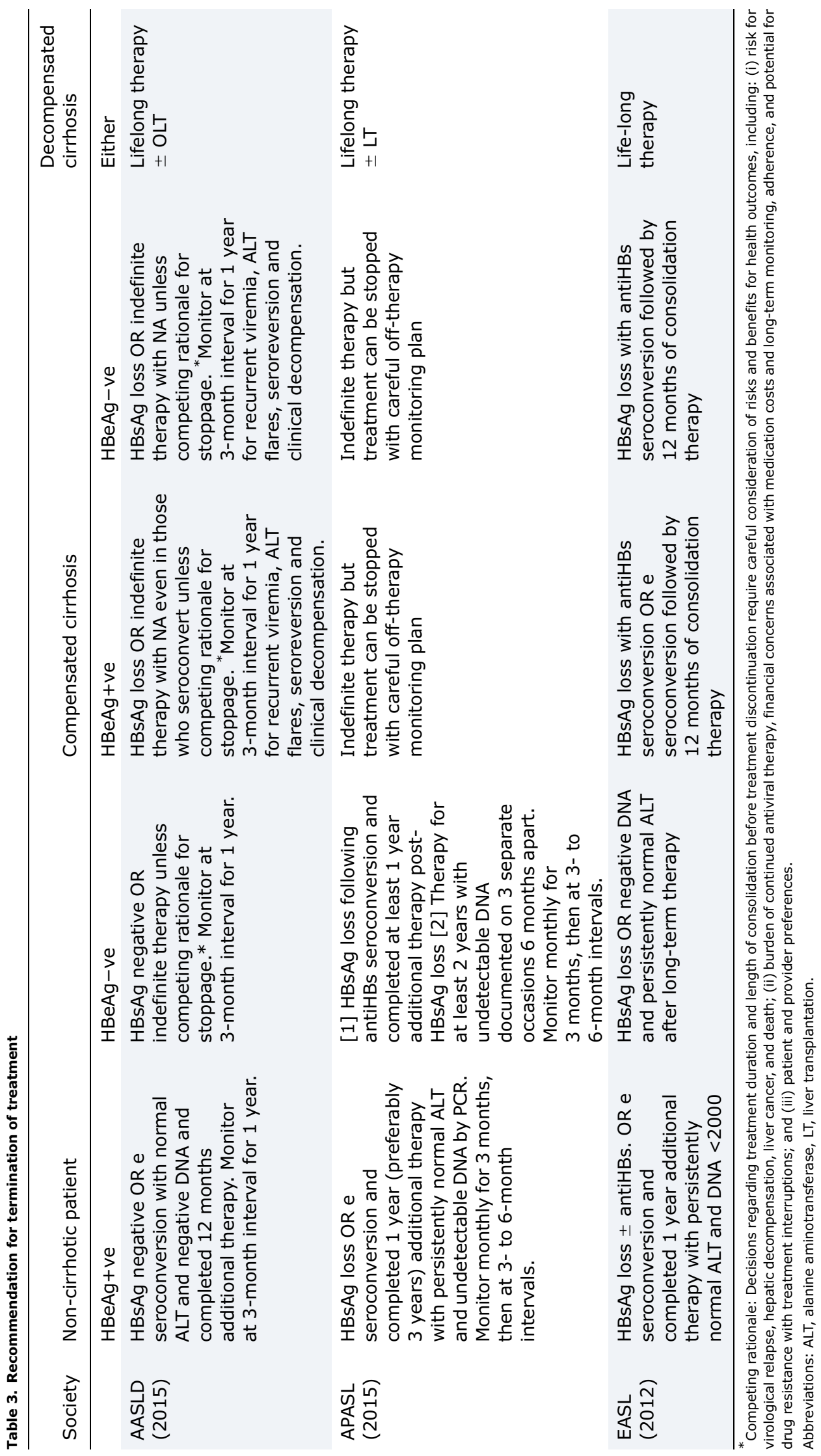


Ray G.: Hepatitis B in India

different mechanisms related to distinctive stages of the viral life cycle (especially those with high and low genetic barrier to resistance and complementary cross-resistance profile) can suppress the virus and decrease synthesis of covalently closed circular DNA in newly-infected cells as well as its pool in chronically-infected cells more effectively than monotherapy; this will possibly restore the immune response to achieve most robust seroconversion, $\mathrm{HBsAg}$ clearance and durable off-treatment response, as well as reduce risk of resistance. This may also lead to a more effective eradication, shorter duration of therapy and dose reductions, thereby resulting in fewer drug side-effects. Unfortunately, higher cost, increased toxicity and drug interactions are potential disadvantages.

Interferons are effective immune response inducers in susceptible patients, but have only mild virus-suppressive activity; whereas, NAs have shown a marked virussuppressive activity in the majority of patients, but have poor immunomodulatory effects. Therefore, the combination of the two could possibly provide both viral suppression and immunomodulation to increase the response rate. ${ }^{111}$

Most of the early series on HBV treatment in India have involved recombinant alpha IFN and LAM, the two earliest drugs to be available either singly or in combination. Daily dosing of IFN escalated the cost and side effects of therapy, and as such efficacy of lower dose was also examined. PegIFN treatment was investigated after 2005 because of its once weekly dosing schedule, but its use was also found to be limited due to very high cost and serious side effects. The availability of potent NAs (ETV, TDF, and telbivudine (LdT)) in recent years has raised hope for better results; but, although these agents can cause sustained viral suppression, complete eradication has not been possible, even with long-term use. The results of various drug trials in India are listed in Table 4.

\section{IFN and its combinations}

IFN $^{112-118}$ in dosages of 3-6 mIU thrice weekly for 16-24 weeks resulted in SVR rates of $21-100 \%$ (6-15\% incremental over end of treatment response (EOTR) rates)), HBeAg loss in $50-100 \%$ and HBsAg loss in $7-15 \%$. Relapse was universal among cases of $\mathrm{e}-\mathrm{ve}$ disease ${ }^{113}$ but one study found high e seroconversion (50\%) that was sustained. ${ }^{114}$ Though short-term results appear good, most of the studies have short follow-up, making sustained drug efficacy difficult to assess. Study of sequential LAM + IFN versus LAM alone for 52 weeks ${ }^{117}$ showed comparable HBeAg loss and EOTR; however, the overall HBeAg loss and SVR was significantly higher in the combination group at week 76, which was better in preventing relapse.

Studies on pegIFN ${ }^{118-121}$ have yielded even more conflicting results. When single agent treatment was administered, long-term SVR in naïve patients was $7.1-14.8 \%$ in response to 24 weeks of treatment (HBeAg loss of $14.8-17 \%$ ) and $50 \%$ in response to 1 year of treatment, with e seroconversion of $25 \%$. SVR rates for the combination treatment of LAM and pegIFN given for 6 months were $50-60 \%$ for treatmentnaïve patients and $33.3 \%$ for treatment-experienced patients, and the corresponding figures for 1 year of therapy were $50 \%$ and $0-60 \%$, all less than EOTR rates. Sequential therapy achieved better SVR and e seroconversion rates.

A review of world literature on such combination therapies $^{111}$ also shows mixed results, which could be due to variability in the three potential phases of the combination therapies. For e+ve disease, simultaneous and sequential combination therapy with IFN + LAM showed a greater ontreatment viral suppression ability and higher SVR than LAM alone, but no difference was observed for the SVR when compared to IFN alone. The simultaneous combination of LAM and pegIFN showed higher SVR than LAM alone, but no difference was observed when compared to pegIFN alone. For e-ve disease, simultaneous IFN plus LAM yielded negative results and high relapse rates, but delayed YMDD selection and for sequential therapy; response rates were similar to monotherapy with IFN or LAM.

Simultaneous pegIFN + LAM was no better than pegIFN alone, and similar sequential therapy was no better than LAM alone. Two meta-analysis (not restricted to treatment-naïve subjects) concluded that, in comparable e+ve populations, pegIFN monotherapy is likely to be equally or more efficacious than conventional IFN and LAM combination therapy; thus, the pegIFN monotherapy was recommended as the treatment of choice, with no added benefit from LAM addition. However, when conventional IFN is used, its combination with LAM should be considered. Most such trials have used the LAM dose of $150 \mathrm{mg} /$ day and IFN doses of 5-10 million units, as well as pegIFN administration of 1 year.

The results of Indian studies with IFNs and their combination by and large seem similar, notwithstanding the lacunae represented by the fact that they are few in number, most are uncontrolled and with small patient number, patient selection criteria is often biased in favour of drug affordability and drug dosing and duration of therapy are variable. However, IFN therapy has been shown not to be cost effective for the number of life-years gained. ${ }^{122}$

\section{NA combinations}

LAM and adefovir (ADV):22,48,123-128 A good number of studies are available on these two drugs, as they are of affordable cost; but, in most studies, the long-term followup is not available, precluding determination of relapse rates. However, the usual high resistance rates with LAM upon long-term use and low efficacy of ADV is evident in Indian patients. LAM given for 6-46 months results in SVR rates of $13-35 \%$, with e seroconversion of $6-40 \%$ (depending on length of therapy), but relapse is about 35\%. Drugresistant mutations reportedly develop in $11-50 \%$ (with $50 \%$ breakthrough reported in one study $)^{123,125,128,129}$ and is higher in those with high baseline DNA and those with longer duration of therapy.

A number of studies have uncovered occurrence of multiple reverse transcriptase mutations with or without association to LAM resistance, even in treatment-naïve subjects. Examples of this include: (a) in $47.9 \%$ patients at pretherapy, but with primary drug resistance mutations in $8.8 \% ;{ }^{130}(\mathrm{~b})$ in genotype $D$ cases, both among treatment-naïve $(65 \%)$ and treated patients $(56.2 \%)$, and cases with reduced drug effectiveness were common among the non-responders to therapy as well as among the treatment-naïve patients, but classical drug resistance mutations were not detected; ${ }^{67}$ (c) core promoter mutations in $68 \%$ of cases with viral breakthrough (vs. $25 \%$ in those without breakthrough) among patients on longterm LAM therapy and being independent of YMDD mutation; $^{131}$ (d) spontaneous drug-resistant mutations in $25 \%$ of treatment-naïve patients; ${ }^{51}$ and (e) naturally occurring HBV surface mutants in $3.5 \%$ of patients at pretherapy and $24.5 \%$ that had developed multiple new S-gene mutations during 


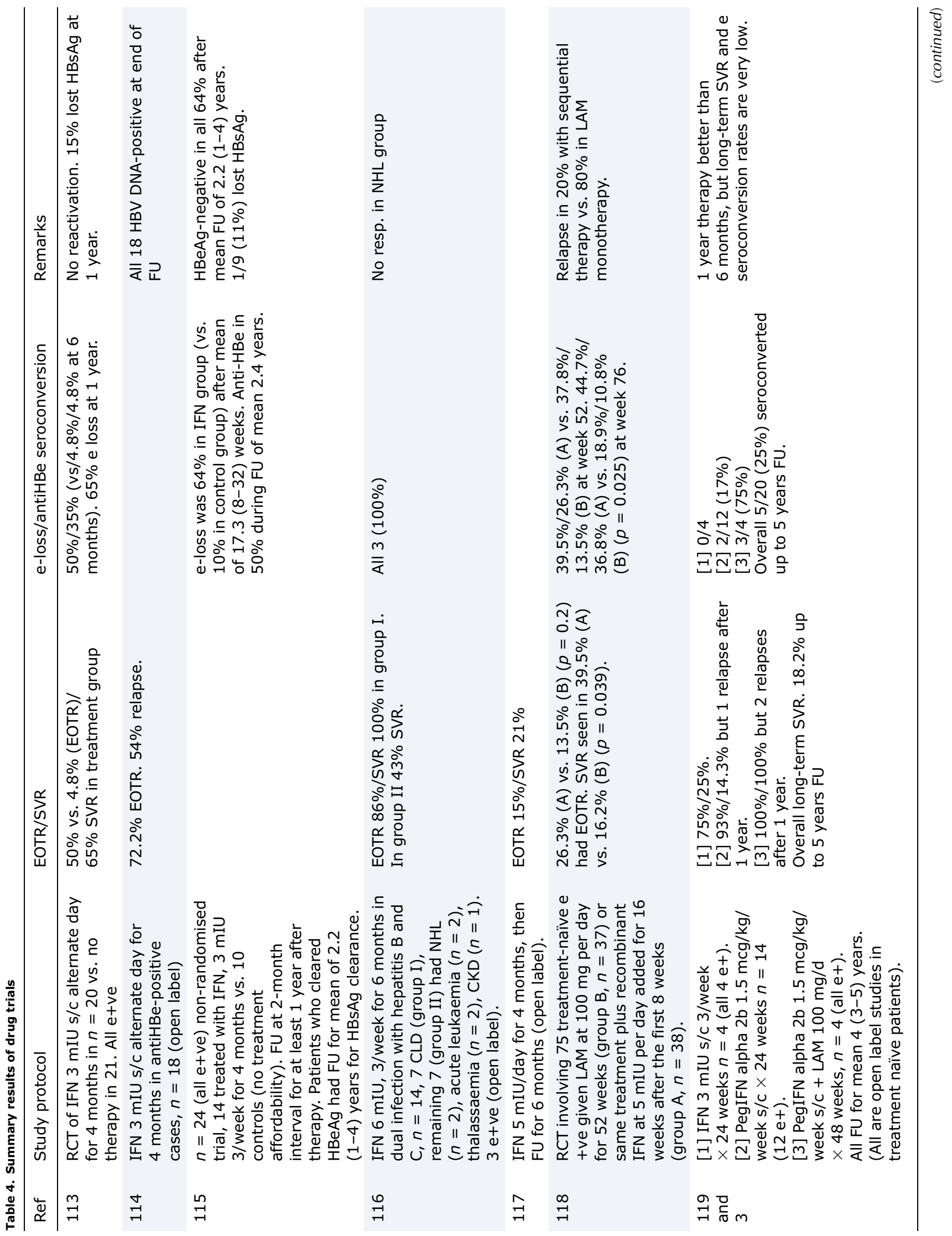




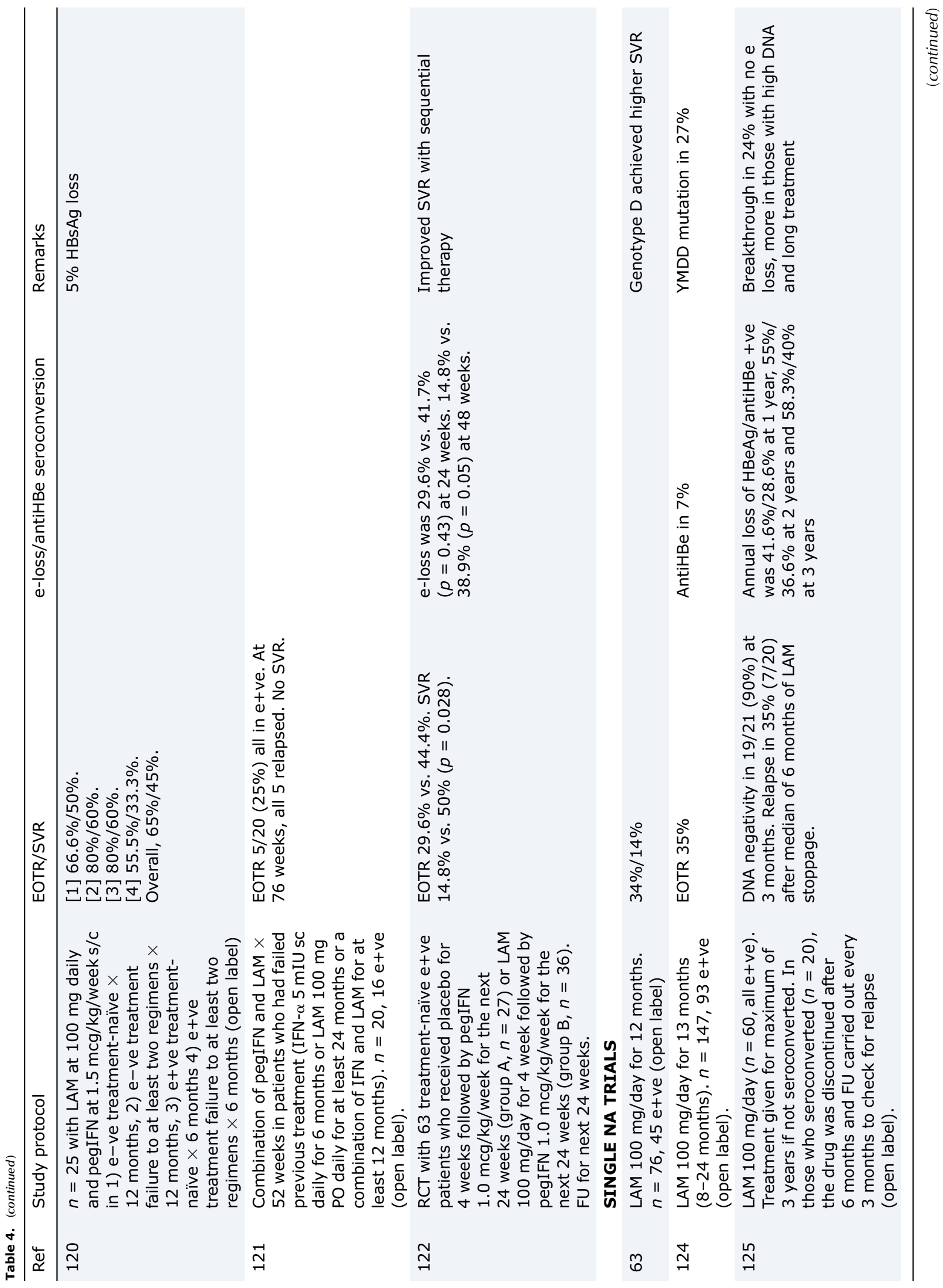




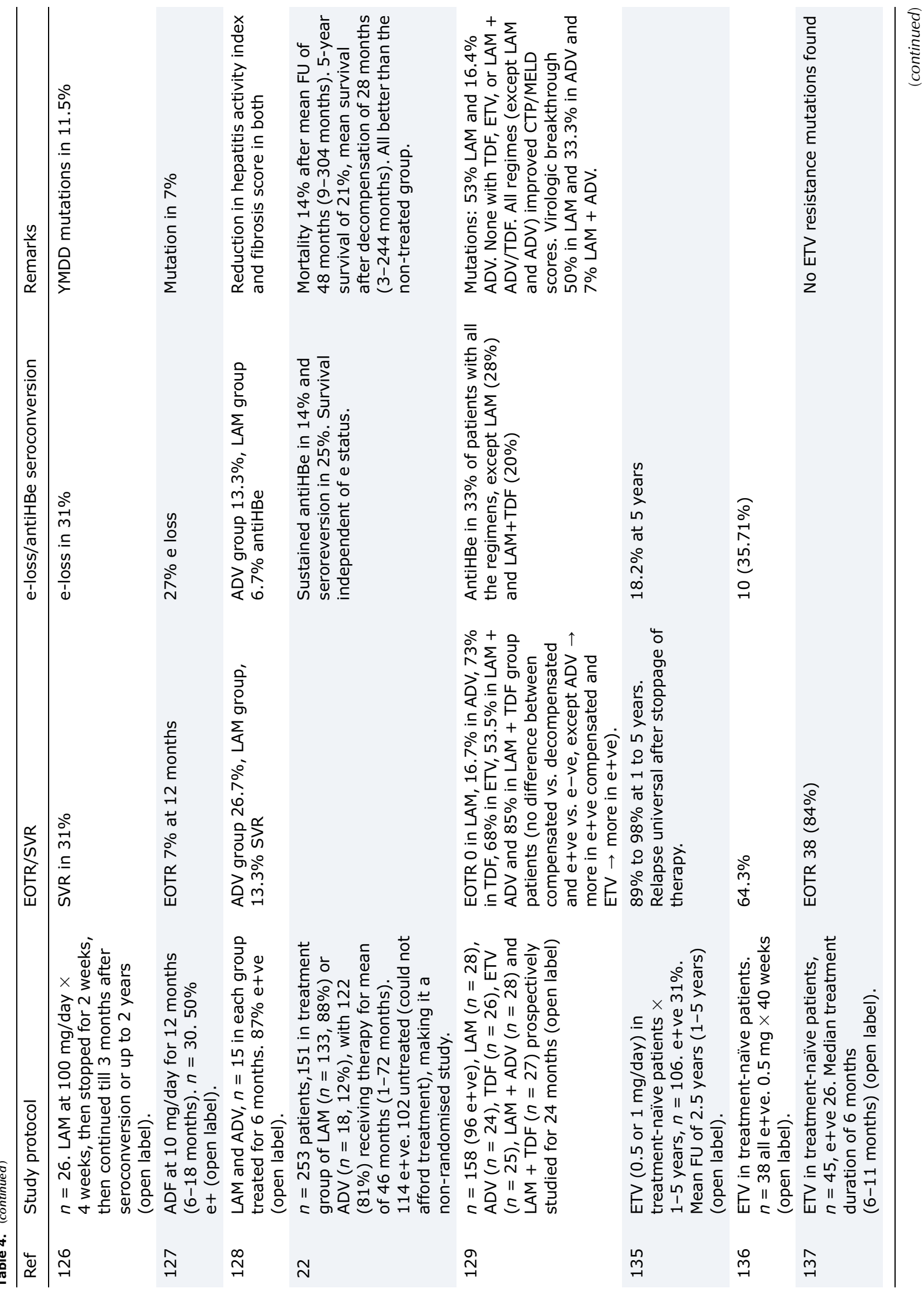




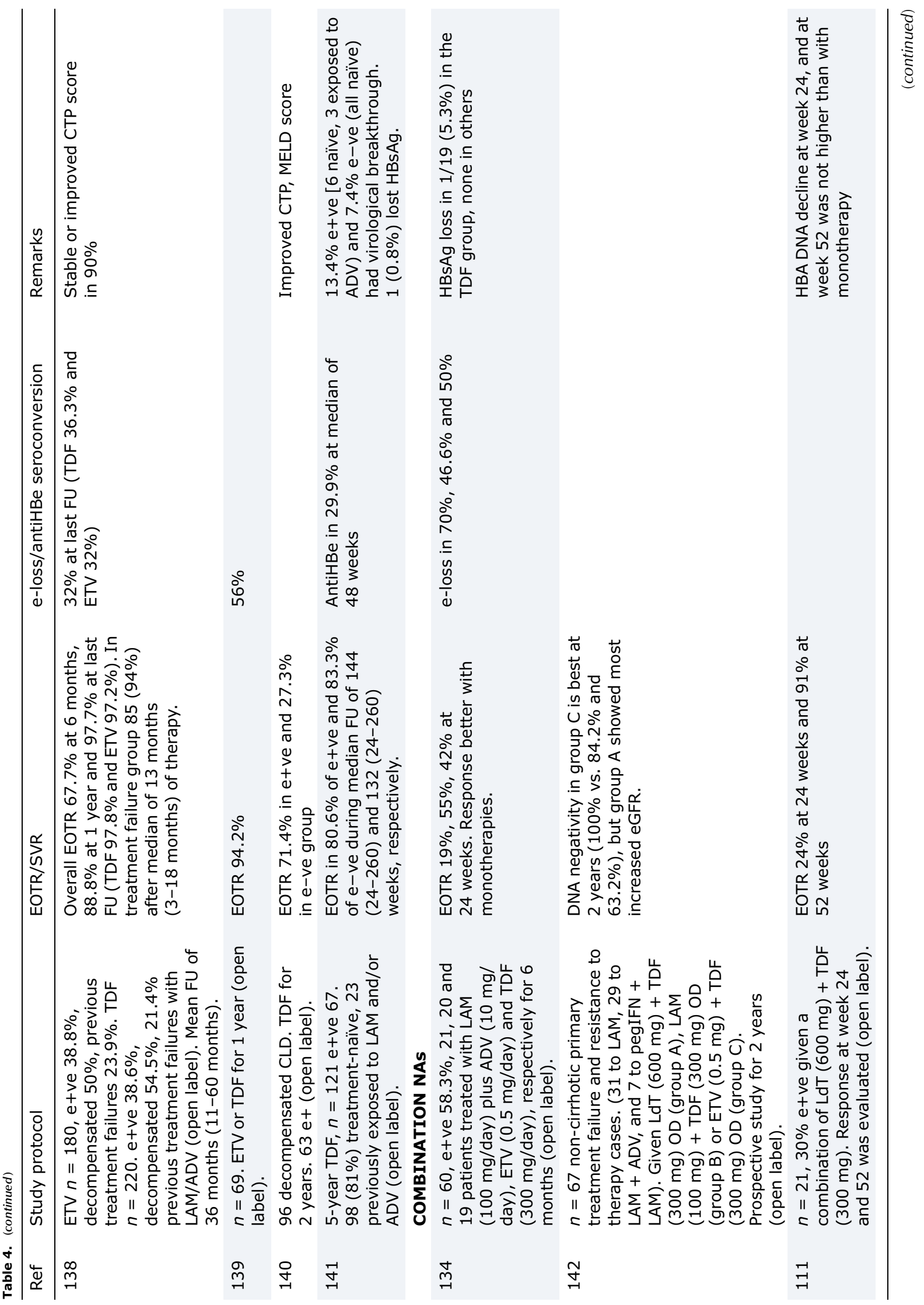


Ray G.: Hepatitis B in India

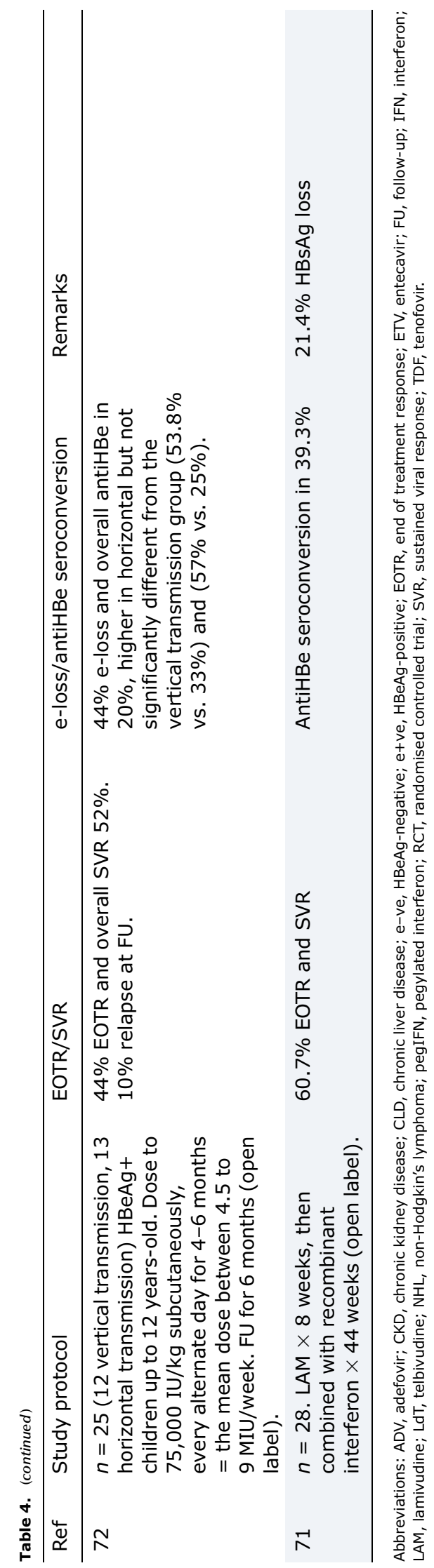

therapy. ${ }^{132}$ All such findings highlight issues therapeutic concern for LAM.

ADV ${ }^{126-128}$ administered for 6-46 months results in viral suppression rates of $7-26.7 \%$ and e seroconversion in $13.3-$ $33 \%$ of cases. Drug-resistant mutations reportedly develop in $7-16.4 \%$ (with $33 \%$ breakthrough). Combination of ADV + LAM $^{128,133}$ administered for 6-24 months was shown to result in rates of viral suppression of $42-53.3 \%$ and e seroconversion of $33-50 \%$. Drug-resistant mutations occurred in only $7 \%$, without any viral breakthrough. However, data on long-term sustained off-therapy response are lacking.

ETV: ${ }^{128,133-138}$ When administered for mean 6-36 months (maximum 5 years), ETV has resulted in viral suppression rates of $55-98 \%$, and even higher rates were achieved with longer therapy duration (with e seroconversion in $18-56 \%)$. One study showed less response in genotype $D$, and another showed better response in e+ve cases; no drug resistance mutations were detected. In the longest study (lasting 5 years), DNA negativity was seen in $98 \%$.

TDF:128,133,137-140 When administered for 6-60 months, TDF resulted in viral suppression rates of $19-98 \%$, which were higher with longer duration of therapy (with e seroconversion in 30-70\%). One study showed less response in genotype D; no drug-resistant mutations were detected. In the longest study (lasting 5 years), DNA negativity was seen in $81.8 \%$.

Combination treatment: Increased dosages of NAs in combination treatment of patients with previous treatment failure yielded good results (e.g. sustained viral suppression rates were achieved with TDF + LAM for 2 years (85\%), ${ }^{128,141}$ TDF + LdT for $1-2$ years $(84-90 \%)^{110,141}$ and ETV + TDF for 2 years $\left.(100 \%)^{141}\right)$, but these results were not better than those achieved with monotherapies.

Thus, although DNA suppression is much higher and resistance is much lower with ETV and TDF, the e seroconversion rates are lower and not much different from that achieved with LAM + ADV; moreover, relapse following discontinuation is almost universal, without significant HBsAg loss even when the treatment is administered on a long-term schedule. Review of worldwide literature ${ }^{111}$ shows agreement. Although higher viral suppression is attained with NAs, the therapeutic effect is not sustained over the longterm or after post-therapy cessation, and higher suppression rates do not translate into higher rates of e seroconversion.

Again, the limitations of most studies include their uncontrolled nature with non-uniform patient selection criteria that are often biased in treatment group in favour of drug affordability, their non-uniform reporting of outcome measures, their inadequate follow-up data on long-term treatment and their uncertainty regarding proper adherence to therapy. Notwithstanding these shortfalls, treatment with pegIFN and NAs give definite survival advantage, ${ }^{3,22}$ with LAM, ETV and TDF showing improvement in Child-Turcotte-Pugh (CTP)/model for end-stage liver disease (MELD) scores and histology. ${ }^{22,127,128,137,140,142}$ A recent meta-analysis of RCT also showed significant benefit of NA therapy on all primary efficacy measures, including virological response, biochemical response, histological response, e seroconversion and HBeAg loss, without adverse effects. ${ }^{143}$

The other major benefit of the NA treatment has been realized in cases of LT with hepatitis B. HBV-related CLD was considered a relative contraindication for LT until the introduction of high-cost HBIg. Recently, the availability of potent NAs (ETV, TDF) has allowed for the possibility of HBIg to be 
Ray G.: Hepatitis B in India

avoided or used at low dose, thus reducing the cost substantially. ${ }^{144}$ In a study of 75 cases of live-donor LT for HBVrelated CLD, among patients who were not given HBIg and were instead treated with NAs (19 with LAM + ADV, 42 with ETV, 12 with TDF, and 2 with ETV + TDF), all patients were found to be DNA-negative at median follow-up of 21 months; moreover, $80 \%$ cleared the $\mathrm{HBsAg}$ and $32 \%$ developed anti-HBs. The $8 \%$ cases of recurrence were all salvaged by changing the NAs used, and there was no mortality. ${ }^{145}$ Another study of LT cases compared the cost of 6 months post-transplant HBIg with that of hyperimmune plasma (containing high antiHBs titre), along with ETV therapy in both groups; the latter was found to be 14-times less costly and to yield low and transient HBsAg reactivity. ${ }^{146}$ The benefit of TDF has also been shown in cases of acute-on-chronic liver failure due to $\mathrm{HBV}$ in reducing mortality for up to 3 months. ${ }^{147}$

\section{Counselling and prevention of transmission}

Awareness about HBV infection is dismally low in India, and this problem is compounded by the absence of symptoms (until late stage of disease) in a large majority of cases. Drug adherence is poor, which decreases the cure rate and increases the spread of infection. Education about HBV infection is crucial for curbing its spread. Published guidelines recommend proper counselling of patients on prevention of transmission, advice on lifestyle (i.e. avoiding high-risk sex, diet, alcohol use and other predisposing factors like unsafe injection practices and tattooing) and importance of continuous adherence to long-term treatment regimens. It is recommended that regular screening and vaccination be performed for high-risk patients (i.e. sexual and household members in close contact with patients/carriers, health care workers, dialysis patients, intravenous drug users, persons who receive multiple blood transfusions, participate in acupuncture, are incarcerated, or on immunosuppressives, biologics or cancer chemotherapy, etc.).

Early treatment of $\mathrm{HBsAg}$-positive mothers and with HBIg for infants born to infected mothers, along with hepatitis $B$ vaccination (at delivery and followed by complete vaccination series) is advocated. Avoidance of sharing of needles and syringes by intravenous drug users and use of separate equipment for HBsAg-positive patients undergoing haemodialysis should be emphasized. Health education not only of the population in general and high-risk population in particular but also of the health care workers is needed regarding avoidance of unnecessary injections, and adopting safe injection practices (like use of aseptic technique and disposable syringes or fluid infusion sets for multiple patients, and taking proper precautions when multiple-dose vials are used). Following universal precautions in health care settings, such as care to prevent needle-stick injuries and implementing post-exposure prophylaxis, can reduce transmission of HBV infection. The unnecessary use of blood transfusions without clear indication should be curbed as well. It appears that most high-risk groups have significant prevalence of occult infection, which needs more vigilant screening.

\section{Provision of safe blood and blood products}

A survey of blood transfusion practices in India showed that screening for transfusion-transmitted infections is unsatisfactory and poorly regulated with poor enforcement of the existing guidelines. A strict audit of blood banking practices is required to prevent transmission of the disease. Use of nucleic acid testing has been proposed for preventing transmission of HBV in Indian blood donors, but this would increase the cost of screening and is not routinely recommended. ${ }^{1}$

There is also a need to map out areas of high endemicity levels within each state in greater detail, especially for tribal areas, which are known to have very high prevalence and are areas that should be the focus of intensive screening and protective measures.

\section{Vaccination}

The most essential step in treatment is prevention of HBV infection by vaccination. A universal immunisation programme (containing vaccination against hepatitis B) was introduced in India in 1985 and became part of the Child Survival and Safe Motherhood programme in 1992. A cost efficacy study ${ }^{148}$ showed that the inclusion of hepatitis $B$ vaccine in India's national immunization program would lead to a reduction in HBV carrier rate from $4.0 \%$ to $1.15 \%$. Vaccination against hepatitis B was piloted in 2002-03 and subsequently integrated into National Rural Health Mission in 2005. Initially, it was introduced in certain districts and cities in 2003, and its subsequent success was followed by its being taken up by 10 states in 2008; full-country coverage started in 2011. ${ }^{149}$

A study of 5-11 year-old rural children in five districts in Andhra Pradesh state, where childhood HBV immunization began in 2003, compared markers of HBV infection in HBVvaccinated children (born in 2003/2004; $n=2674$ ) and HBVunvaccinated children (born in 2001/2002; $n=2350$ ). Though antiHBs protective level $(10 \mathrm{mlU} / \mathrm{mL})$ was found in $59 \%$ of those vaccinated by 6 years-old, only $13 \%$ had protective levels at 11 years-old; moreover, although antiHBc was higher in the unvaccinated group $(1.79 \%)$ it was still present in the vaccinated group (1.05\%) and the $\mathrm{HBsAg}$ carrier rate was similar $(0.17 \%$ and $0.15 \%) .{ }^{150}$ Some impact within the paediatric population was evident, however, according to the major decrease in HBV as aetiology of HCC observed in recent years, ${ }^{151}$ like in Taiwan. That proper vaccination can be efficacious in reducing the disease burden is demonstrated by its recent success in tribals of Andaman and Nicobar Islands. ${ }^{152}$

Since it takes at least 15-20 years from the time of vaccination for any meaningful impact on overall adult disease prevalence to be made, time is still not ripe to observe this impact. Also, the type of vaccine, the number, amount and interval of dosage (including booster), and effectiveness in high-risk and immune-jeopardised groups needs further study. Research into development of more efficacious newer vaccines should be encouraged. ${ }^{153}$

\section{Conclusions}

Hepatitis B is a significant public health problem in India, yet disease awareness among its people-the key to decreasing disease burden-is dismally low. The majority of disease cases progress silently and patients present in advanced stages, when decompensated CLD or HCC has already developed. With the currently available drugs, complete cure is not possible and the aim is long-term suppression of the virus by prolonged therapy, which itself can lead to poor treatment adherence along with prohibitive cost of therapy. 
Ultimately, this underlies poor disease control, with progression and spread of infection.

Although a programme aiming to provide countrywide vaccination coverage was launched recently, the logistics are not yet adequate for proper disease control. As the arrival of novel drugs that target viral life cycle or modulate host immune response (which might lead to disease "cure") is eagerly awaited, the present emphasis should be on (1) health education of general and high-risk populations regarding lifestyle, preventive measures, early disease detection and proper adherence to drugs and of health care workers on adoption of proper precautions while carrying out their duties, and (2) aggressive vaccination strategies in the population, especially for tribals and high-risk groups.

\section{Conflict of interest}

The author has no conflict of interest related to this publication.

\section{Author contributions}

Collected, analysed and interpreted all data and wrote the manuscript (GR).

\section{References}

[1] Puri P. Tackling the hepatitis B disease burden in India. J Clin Exp Hepatol 2014;4:312-319. doi: 10.1016/j.jceh.2014.12.004.

[2] Ray G, Ghoshal UC, Banerjee PK, Pal BB, Dhar K, Pal AK, et al. Aetiological spectrum of chronic liver disease in eastern India. Trop Gastroenterol 2000; 21:60-62.

[3] Ray G. Trends of chronic liver disease in a tertiary care referral hospital in Eastern India. Indian J Public Health 2014;58:186-194. doi: 10.4103/ 0019-557X.138630.

[4] Sarin SK, Chari S, Sundaram KR, Ahuja RK, Anand BS, Broor SL. Young v adult cirrhotics: a prospective, comparative analysis of the clinical profile, natural course and survival. Gut 1988;29:101-107. doi: 10.1136/gut.29. 1.101

[5] Sharma BC, Sharma P, Agrawal A, Sarin SK. Secondary prophylaxis of hepatic encephalopathy: an open-label randomized controlled trial of lactulose versus placebo. Gastroenterology 2009;137:885-891, 891.e1. doi: 10.1053/j.gastro.2009.05.056.

[6] Prasad S, Dhiman RK, Duseja A, Chawla YK, Sharma A, Agarwal R. Lactulose improves cognitive functions and health-related quality of life in patients with cirrhosis who have minimal hepatic encephalopathy. Hepatology 2007;45:549-559. doi: 10.1002/hep.21533.

[7] Jhajharia A, Soni A, Pokharna R, Ashdhir P, Sharma SS, Nepalia S. Spectrum of chronic liver disease admitted to a medical college hospital in northern India: is there cause for concern? Indian J Gastroenterol 2014;33:480-481. doi: 10.1007/s12664-014-0465-z.

[8] Sidhu SS, Goyal O, Parker RA, Kishore H, Sood A. Rifaximin vs. lactulose in treatment of minimal hepatic encephalopathy. Liver Int 2016;36:378-385. doi: 10.1111/liv.12921.

[9] Borse N, Sawant P, Gala B. Assessment of renal and hepatic hemodynamics in cirrhosis of liver. Indian J Gastroenterol 2002;21:213-215.

[10] Sasidharan M, Nistala S, Narendhran RT, Murugesh M, Bhatia SJ, Rathi PM. Nutritional status and prognosis in cirrhotic patients. Trop Gastroenterol 2012;33:257-264. doi: 10.7869/tg.2012.67.

[11] Baijal R, Amarapurkar D, Praveen Kumar HR, Kulkarni S, Shah N, Doshi S, et al. A multicenter prospective study of infections related morbidity and mortality in cirrhosis of liver. Indian J Gastroenterol 2014;33:336-342. doi: 10.1007/s12664-014-0461-3.

[12] Saravanan S, Velu V, Kumarasamy N, Shankar EM, Nandakumar S, Murugavel KG, et al. The prevalence of hepatitis B virus and hepatitis C virus infection among patients with chronic liver disease in South India. Int J Infect Dis 2008;12:513-518. doi: $10.1016 / j$.ijid.2008.02.006.

[13] Goel A, Madhu K, Zachariah U, Sajith KG, Ramachandran J, Ramakrishna B, et al. A study of aetiology of portal hypertension in adults (including the elderly) at a tertiary centre in southern India. Indian J Med Res 2013; 137:922-927.
[14] Kumar A. Current practices in management of hepatocellular carcinoma in India: results of an online survey. J Clin Exp Hepatol 2014;4:S140-S146. doi: 10.1016/j.jceh.2014.07.001.

[15] Pal S, Ramachandran J, Kurien RT, Eapen A, Ramakrishna B, Keshava SN, et al. Hepatocellular carcinoma continues to be diagnosed in the advanced stage: profile of hepatocellular carcinoma in a tertiary care hospital in South India. Trop Doct 2013;43:25-26. doi: 10.1177/0049475512473600.

[16] Arora A, Sharma P, Tyagi $P$, Singla V, Arora V, Bansal N, et al. Hepatitis B virus infection can cause hepatocellular carcinoma in less advanced liver cirrhosis: A comparative study of 142 patients from North India. J Clin Exp Hepatol 2013;3:288-295. doi: 10.1016/j.jceh.2013.08.007.

[17] Saini N, Bhagat A, Sharma S, Duseja A, Chawla Y. Evaluation of clinical and biochemical parameters in hepatocellular carcinoma: experience from an Indian center. Clin Chim Acta 2006;371:183-186. doi: 10.1016/j.cca. 2006.02.038.

[18] Kumar R, Saraswat MK, Sharma BC, Sakhuja P, Sarin SK. Characteristics of hepatocellular carcinoma in India: a retrospective analysis of 191 cases. QJM 2008;101:479-485. doi: 10.1093/qjmed/hcn033.

[19] Paul SB, Chalamalasetty SB, Vishnubhatla S, Madan K, Gamanagatti SR, Batra Y, et al. Clinical profile, etiology and therapeutic outcome in 324 hepatocellular carcinoma patients at a tertiary care center in India. Oncology 2009;77:162-171. doi: 10.1159/000231886.

[20] Sarma MP, Asim M, Medhi S, Bharathi T, Diwan R, Kar P. Viral genotypes and associated risk factors of hepatocellular carcinoma in India. Cancer Biol Med 2012;9:172-181. doi: 10.7497/j.issn.2095-3941.2012.03.004.

[21] Patil PS, Mohandas KM, Bhatia S], Mehta SA. Serum ferritin and the risk of hepatocellular carcinoma in chronic liver disease of viral etiology: a casecontrol study. Indian J Gastroenterol 2014;33:12-18. doi: 10.1007/ s12664-013-0367-5.

[22] Das K, Das K, Datta S, Pal S, Hembram JR, Dhali GK, et al. Course of disease and survival after onset of decompensation in hepatitis $B$ virus-related cirrhosis. Liver Int 2010;30:1033-1042. doi: 10.1111/j.1478-3231.2010. 02255.x.

[23] Nayak NC, Jain D, Vasdev N, Gulwani H, Saigal S, Soin A. Etiologic types of end-stage chronic liver disease in adults: analysis of prevalence and their temporal changes from a study on native liver explants. Eur J Gastroenterol Hepatol 2012;24:1199-1208. doi: 10.1097/MEG.0b013e32835643f1.

[24] Islami F, Dikshit R, Mallath MK, Jemal A. Primary liver cancer deaths and related years of life lost attributable to hepatitis $B$ and $C$ viruses in India. Cancer Epidemiol 2016;40:79-86. doi: 10.1016/j.canep.2015.11.012.

[25] Rizvi M, Azam M, Sultan A, Shukla I, Malik A, Ajmal MR, et al. Prevalence of genotype $D$ in chronic liver disease patients with occult HBV infection in northern region of India. Indian J Pathol Microbiol 2014;57:537-541. doi: 10.4103/0377-4929.142643.

[26] Dixit VK, Panda K, Babu AV, Kate MP, Mohapatra A, Vashistha P, et al. Asymptomatic chronic hepatitis $B$ virus infection in northern India. Indian J Gastroenterol 2007;26:159-161.

[27] Guptan RC, Thakur V, Sarin SK, Banerjee K, Khandekar P. Frequency and clinical profile of precore and surface hepatitis B mutants in Asian-Indian patients with chronic liver disease. Am J Gastroenterol 1996;91: 1312-1317. doi: 10.1097/00042737-199610000-00019.

[28] Kumar A, Tiwari BK, Chaudhary AK, Pant S, Narang S. Identification of a hepatitis $B$ virus core promoter mutant by PCR- RFLP in patients suffering from chronic liver disease, Uttar Pradesh, India. Asian Pac J Cancer Prev 2009;10:1173-1175.

[29] Kumar M, Sarin SK, Hissar S, Pande C, Sakhuja P, Sharma BC, et al. Virologic and histologic features of chronic hepatitis $B$ virus-infected asymptomatic patients with persistently normal ALT. Gastroenterology 2008;134: 1376-1384. doi: 10.1053/j.gastro.2008.02.075.

[30] Dwibedi B, Sabat J, Ho LM, Singh SP, Sahu P, Arora R, et al. Molecular epidemiology of hepatitis $\mathrm{B}$ virus in primitive tribes of Odisha, eastern India. Pathog Glob Health 2014;108:362-368. doi: 10.1179/2047773214Y. 0000000165.

[31] Chandra PK, Banerjee A, Datta S, Chakravarty R. G1862T mutation among hepatitis B virus-infected individuals: association with viral genotypes and disease outcome in Kolkata, Eastern India. Intervirology 2007;50: 173-180. doi: 10.1159/000098960.

[32] Amarapurkar DN, Baijal R, Kulshrestha PP, Agal S, Chakraborty MR, Pramanik SS. Profile of hepatitis B e antigen-negative chronic hepatitis B. Indian J Gastroenterol 2002;21:99-101.

[33] Shanmugam S, Velu V, Nandakumar S, Madhavan V, Shanmugasundaram U, Shankar EM, et al. Low frequency of precore mutants in anti-hepatitis B e antigen positive subjects with chronic hepatitis B virus infection in Chennai, Southern India. J Microbiol Biotechnol 2008;18:1722-1728.

[34] Radhakrishnan S, Abraham P, Raghuraman S, Kabrawala M, Eapen CE, Sridharan $G$, et al. Infrequent occurrence of silent HBV infection among Indian patients with chronic liver disease. Indian J Gastroenterol 2001; 20:87-89.

[35] Ramachandran J, Ismail AM, Chawla G, Fletcher GJ, Goel A, Eapen CE, et al. Serum HBsAg quantification in treatment-naïve Indian patients with chronic 
hepatitis B. Indian J Gastroenterol 2014;33:131-135. doi: 10.1007/ s12664-013-0395-1.

[36] Chowdhury A, Santra A, Chakravorty R, Banerji A, Pal S, Dhali GK, et al. Community-based epidemiology of hepatitis $B$ virus infection in West Bengal, India: prevalence of hepatitis $\mathrm{B}$ e antigen-negative infection and associated viral variants. J Gastroenterol Hepatol 2005;20:1712-1720. doi: $10.1111 / \mathrm{j} .1440-1746.2005 .04070 . x$.

[37] Valliammai T, Thyagarajan SP, Zuckerman AJ, Harrison TJ. Precore and core mutations in HBV from individuals in India with chronic infection. J Med Virol 1995;45:321-325. doi: 10.1002/jmv.1890450315.

[38] Agarwal AK, Sen S, Banerjee D, Srivastava R, Praharaj AK. Distribution of hepatitis $B$ virus genotype and cancer predicting precore and basal core promoter mutations. Med J Armed Forces India 2015;71:225-232. doi: 10.1016/j.mjafi.2015.04.003.

[39] Kumar GT, Kazim SN, Kumar M, Hissar S, Chauhan R, Basir SF, et al. Hepatitis $B$ virus genotypes and hepatitis $B$ surface antigen mutations in family contacts of hepatitis $B$ virus infected patients with occult hepatitis B virus infection. J Gastroenterol Hepatol 2009;24:588-598. doi: 10.1111/ j.1440-1746.2008.05727.x.

[40] Biswas A, Panigrahi R, Chandra PK, Banerjee A, Datta S, Pal M, et al. Characterization of the occult hepatitis $B$ virus variants circulating among the blood donors from eastern India. Scientific World Journal 2013;2013: 212704. doi: 10.1155/2013/212704.

[41] Bhattacharya H, Bhattacharya D, Nagarajan M, Reesu R, Roy S, Attayur PS Prevalence of mutations in basal core promoter and precore region of hepatitis $B$ virus in vaccinated and nonvaccinated individuals of the aboriginal Nicobarese tribe of Car Nicobar Island, India. Intervirology 2014;57: 357-364. doi: 10.1159/000365756.

[42] Sood AK, Pangotra C, Manrai M. Prevalence of occult hepatitis B infection in patients visiting tertiary care hospital. Med J Armed Forces India 2016;72: 140-144. doi: 10.1016/j.mjafi.2016.02.006.

[43] Jayshree RS, Sridhar H, Devi GM. Surface, core, and X genes of hepatitis B virus in hepatocellular carcinoma: an in situ hybridization study. Cancer 2003;99:63-67. doi: 10.1002/cncr.10954

[44] Gopalakrishnan D, Keyter M, Shenoy KT, Leena KB, Thayumanavan L, Thomas V, et al. Hepatitis B virus subgenotype A1 predominates in liver disease patients from Kerala, India. World J Gastroenterol 2013;19: 9294-9306. doi: 10.3748/wjg.v19.i48.9294.

[45] Banerjee A, Datta S, Chandra PK, Roychowdhury S, Panda CK, Chakravarty R. Distribution of hepatitis B virus genotypes: phylogenetic analysis and virological characteristics of genotype C circulating among HBV carriers in Kolkata, Eastern India. World J Gastroenterol 2006;12:5964-5971. doi: 10. 3748/wjg.v12.i37.5964.

[46] Biswas A, Banerjee A, Chandra PK, Datta S, Panigrahi R, Dutta D, et al. Variations in the functional domain of basal core promoter of hepatitis $B$ virus among Eastern Indian patients with prevalence of genotypes $A, C$ and D among the same ethnic population. J Med Virol 2011;83:253-260. doi: $10.1002 / j m v .21979$.

[47] Thakur V, Guptan RC, Kazim SN, Malhotra V, Sarin SK. Profile, spectrum and significance of HBV genotypes in chronic liver disease patients in the Indian subcontinent. J Gastroenterol Hepatol 2002;17:165-170. doi: 10.1046/j. 1440-1746.2002.02605.x.

[48] Thakur V, Sarin SK, Rehman S, Guptan RC, Kazim SN, Kumar S. Role of HBV genotype in predicting response to lamivudine therapy in patients with chronic hepatitis B. Indian J Gastroenterol 2005;24:12-25.

[49] Chattopadhyay S, Das BC, Kar P. Hepatitis B virus genotypes in chronic liver disease patients from New Delhi, India. World J Gastroenterol 2006;12: 6702-6706. doi: 10.3748/wjg.v12.i41.6702.

[50] Madan K, Batra Y, Sreenivas V, Mizokami M, Tanaka Y, Chalamalasetty SB, et al. HBV genotypes in India: do they influence disease severity? Hepato Res 2009;39:157-163. doi: 10.1111/j.1872-034X.2008.00417.x.

[51] Tuteja A, Siddiqui AB, Madan K, Goyal R, Shalimar, Sreenivas V, et al. Mutation profiling of the hepatitis $B$ virus strains circulating in North Indian population. PLoS One 2014;9:e91150. doi: 10.1371/journal.pone.0091150.

[52] Ismail AM, Puhazhenthi KS, Sivakumar ], Eapen CE, Kannangai R, Abraham P. Molecular epidemiology and genetic characterization of hepatitis $B$ virus in the Indian subcontinent. Int J Infect Dis 2014;20:1-10. doi: 10.1016/j.ijid. 2013.12.007.

[53] Vivekanandan P, Abraham P, Sridharan G, Chandy G, Daniel D, Raghuraman S et al. Distribution of hepatitis B virus genotypes in blood donors and chronically infected patients in a tertiary care hospital in southern India. Clin Infect Dis 2004;38:e81-e86. doi: 10.1086/383144.

[54] Saikia A, Bose M, Barman NN, Deka M, Thangkhiew RS, Bose S. Molecular epidemiology of HBV infection in chronic hepatitis B virus infected patients in northeast India. J Med Virol 2015;87:1539-1548. doi: 10.1002/jmv. 24207.

[55] Borkakoty B], Mahanta J, Biswas D. Circulating genotypes of hepatitis B virus in Arunachal Pradesh. Indian J Med Res 2008;127:65-70.

[56] Kumar K, Kumar M, Rahaman SH, Singh TB, Patel SK, Nath G. Distribution of Hepatitis $B$ virus genotypes among healthy blood donors in eastern part of North India. Asian J Transfus Sci 2011;5:144-149. doi: 10.4103/09736247.83240 .

[57] Kumar A, Dwivedi M, Misra SP, Misra V, Narang S, Pandey R, et al. Distribution of hepatitis $B$ virus genotypes and its association with severity of liver disease in patients with chronic hepatitis B in uttar pradesh, India. Indian J Virol 2011;22:24-28. doi: 10.1007/s13337-011-0034-3.

[58] Kumar A, Kumar SI, Pandey R, Naik S, Aggarwal R. Hepatitis B virus genotype $A$ is more often associated with severe liver disease in northern India than is genotype D. Indian J Gastroenterol 2005;24:19-22.

[59] Gandhe SS, Chadha MS, Arankalle VA. Hepatitis B virus genotypes and serotypes in western India: lack of clinical significance. J Med Virol 2003; 69:324-330. doi: 10.1002/jmv.10292.

[60] Sarkar N, Pal A, Das D, Saha D, Biswas A, Bandopadhayay B, et al. Virological characteristics of acute hepatitis $B$ in Eastern India: critical differences with chronic infection. PLoS One 2015;10:e0141741. doi: 10.1371/ journal.pone.0141741.

[61] Sharma S, Sharma B, Singla B, Chawla YK, Chakraborti A, Saini N, et al. Clinical significance of genotypes and precore/basal core promoter mutations in HBV related chronic liver disease patients in North India. Dig Dis Sci 2010;55:794-802. doi: 10.1007/s10620-009-1083-y.

[62] Chauhan R, Singh AK, Rooge S, Varshney A, Kumar M, Sarin SK. Analysis of hepatitis $B$ virus genotype changes in patients with chronic hepatitis B infection on tenofovir therapy. J Med Virol 2016;88:1364-1375. doi: 10.1002/ jmv.24489.

[63] Chauhan R, Kazim SN, Bhattacharjee J, Sakhuja P, Sarin SK. Basal core promoter, precore region mutations of $\mathrm{HBV}$ and their association with $\mathrm{e}$ antigen, genotype, and severity of liver disease in patients with chronic hepatitis B in India. J Med Virol 2006;78:1047-1054. doi: 10.1002/jmv. 20661.

[64] Datta S, Roychoudhury S, Ghosh A, Dasgupta D, Ghosh A, Chakraborty BC, et al. Distinct distribution pattern of hepatitis $B$ virus genotype $C$ and $D$ in liver tissue and serum of dual genotype infected liver cirrhosis and hepatocellular carcinoma patients. PLoS One 2014;9:e102573. doi: 10.1371/ journal.pone. 0102573 .

[65] Mukherjee RM, Balkumar Reddy P, Sasikala M, Nagaraja Rao P, Nageshwar Reddy D. Identification of genotype $B$ among hepatitis $B$ virus-infected patients in Hyderabad, India. Ann Hepatol 2009;8:269-270.

[66] Biswas A, Panigrahi R, Pal M, Chakraborty S, Bhattacharya P, Chakrabarti S, et al. Shift in the hepatitis B virus genotype distribution in the last decade among the HBV carriers from eastern India: possible effects on the disease status and HBV epidemiology. J Med Virol 2013;85:1340-1347. doi: 10. $1002 / j m v .23628$.

[67] Panigrahi R, Biswas A, De BK, Chakrabarti S, Chakravarty R. Characterization of antiviral resistance mutations among the Eastern Indian Hepatitis $B$ virus infected population. Virol J 2013;10:56. doi: 10.1186/1743-422X-1056.

[68] Batham A, Narula D, Toteja T, Sreenivas V, Puliyel JM. Sytematic review and meta-analysis of prevalence of hepatitis B in India. Indian Pediatr 2007;44: 663-674.

[69] Shah I, Bhatnagar S. Clinical profile of chronic hepatobiliary disorders in children: experience from tertiary referral centre in Western India. Trop Gastroenterol 2010;31:108-110.

[70] Srivastava A, Mathias A, Yachha SK, Aggarwal R. Occult hepatitis B infection in children with chronic liver disease. Eur J Gastroenterol Hepatol 2015;27: 375-377. doi: 10.1097/MEG.0000000000000294.

[71] Gupta S, Gupta R, Joshi YK, Singh S. Role of horizontal transmission in hepatitis $B$ virus spread among household contacts in north India. Intervirology 2008;51:7-13. doi: 10.1159/000118790.

[72] Thakur V, Kazim SN, Guptan RC, Malhotra V, Sarin SK. Molecular epidemiology and transmission of hepatitis B virus in close family contacts of HBVrelated chronic liver disease patients. J Med Virol 2003;70:520-528. doi: 10.1002/jmv.10426

[73] Chakravarty R, Chowdhury A, Chaudhuri S, Santra A, Neogi M, Rajendran K, et al. Hepatitis $B$ infection in Eastern Indian families: need for screening of adult siblings and mothers of adult index cases. Public Health $2005 ; 119$ 647-654. doi: 10.1016/j.puhe.2004.09.007.

[74] Poddar U, Yachha SK, Agarwal J, Krishnani N. Cure for immune-tolerant hepatitis $B$ in children: is it an achievable target with sequential combo therapy with lamivudine and interferon? J Viral Hepat 2013;20:311-316. doi: $10.1111 /$ jvh.12007.

[75] Guptan RC, Thakur V, Malhotra V, Sarin SK. Recombinant interferon therapy in Indian children with HBV related chronic liver disease. Indian Pediatr 2002;39:462-467.

[76] Kumar R, Singla V, Kacharya Sk. Impact and management of hepatitis B and hepatitis C virus co-infection in HIV patients. Trop Gastroenterol 2008;29: 136-147.

[77] Saha D, Pal A, Biswas A, Panigrahi R, Sarkar N, Sarkar J, et al. Characterization of treatment-naive HIV/HBV co-infected patients attending ART clinic of a tertiary healthcare centre in eastern India. PLoS One 2013;8: e73613. doi: 10.1371/journal.pone.0073613. 
[78] Sawant S, Agrawal S, Shastri J. Seroprevalence of hepatitis B and hepatitis $C$ virus infection among HIV infected patients in Mumbai. Indian J Sex Transm Dis 2010;31:126. doi: 10.4103/0253-7184.75025.

[79] Pal A, Sarkar N, Saha D, Guha SK, Saha B, Chakrabarti S, et al. High incidence of lamivudine-resistance-associated vaccine-escape HBV mutants among HIV-coinfected patients on prolonged antiretroviral therapy. Antivir Ther 2015;20:545-554. doi: 10.3851/IMP2942.

[80] Saravanan S, Velu V, Kumarasamy N, Nandakumar S, Murugavel KG, Balakrishnan $\mathrm{P}$, et al. Coinfection of hepatitis $\mathrm{B}$ and hepatitis $\mathrm{C}$ virus in HIVinfected patients in south India. World J Gastroenterol 2007;13: 5015-5020. doi: 10.3748/wjg.v13.i37.5015.

[81] Gupta S, Singh S. Hepatitis B and C virus co-infections in human immunodeficiency virus positive North Indian patients. World J Gastroenterol 2006; 12:6879-6883. doi: 10.3748/wjg.v12.i42.6879.

[82] Panigrahi R, Majumder S, Gooptu M, Biswas A, Datta S, Chandra PK, et al. Occult HBV infection among anti-HBc positive HIV-infected patients in apex referral centre, Eastern India. Ann Hepatol 2012;11:870-875.

[83] Chandra N, Joshi N, Raju YS, Kumar A, Teja VD. Hepatitis B and/or C co-infection in HIV infected patients: a study in a tertiary care centre from South India. Indian J Med Res 2013;138:950-954.

[84] Isaakidis P, Mansoor $H$, Zachariah R, Da Silva EA, Varghese B, Deshpande A, et al. Treatment outcomes in a cohort of patients with chronic hepatitis $B$ and human immunodeficiency virus co-infection in Mumbai, India. Int Health 2012;4:239-245. doi: 10.1016/j.inhe.2012.04.002.

[85] Reddy GA, Dakshinamurthy KV, Neelaprasad P, Gangadhar T, Lakshmi V. Prevalence of HBV and HCV dual infection in patients on haemodialysis. Indian J Med Microbiol 2005;23:41-43. doi: 10.4103/0255-0857.13872.

[86] Chattopadhyay S, Rao S, Das BC, Singh NP, Kar P. Prevalence of transfusiontransmitted virus infection in patients on maintenance hemodialysis from New Delhi, India. Hemodial Int 2005;9:362-366. doi: 10.1111/j.15424758.2005.01154.x

[87] Rathod JR, Sirsat RA, Shah BV. Renal transplant in hepatitis B and C positive patients-a ten years experience. J Assoc Physicians India 2002; 50:766-770.

[88] Potsangbam G, Yadav A, Chandel N, Rathi M, Sharma A, Kohli HS, et al. Challenges in containing the burden of hepatitis $B$ infection in dialysis and transplant patients in India. Nephrology (Carlton) 2011;16:383-388. doi: 10.1111/j.1440-1797.2010.01429.x.

[89] Chandra M, Khaja MN, Hussain MM, Poduri CD, Farees N, Habeeb MA, et al. Prevalence of hepatitis $B$ and hepatitis $C$ viral infections in Indian patients with chronic renal failure. Intervirology 2004;47:374-376. doi: 10.1159/ 000080883

[90] Amarapurkar DN, Kumar A, Vaidya S, Murti P, Bichile SK, Kalro RH, et al. Frequency of hepatitis $B, C$ and $D$ and human immunodeficiency virus infections in multi-transfused thalassemics. Indian J Gastroenterol 1992; $11: 80-81$.

[91] De M, Banerjee D, Chandra S, Bhattacharya DK. HBV \& HIV seropositivity in multi-transfused haemophilics \& thalassaemics in eastern India. Indian J Med Res 1990;91:63-66.

[92] Sabat J, Dwibedi B, Dash L, Kar SK. Occult HBV infection in multi transfused thalassemia patients. Indian J Pediatr 2015;82:240-244. doi: 10.1007/ s12098-014-1490-8.

[93] Ghosh K, Joshi SH, Shetty S, Pawar A, Chipkar S, Pujari V, et al. Transfusion transmitted diseases in haemophilics from western India. Indian J Med Res 2000;112:61-64.

[94] Guruprasad B, Kavitha S, Aruna Kumari BS, Vijaykumar BR, Sumati BG, Mahua $S$, et al. Risk of hepatitis $B$ infection in pediatric acute lymphoblastic leukemia in a tertiary care center from South India. Pediatr Blood Cancer 2014;61:1616-1619. doi: 10.1002/pbc. 25065.

[95] Solomon SS, Srikrishnan AK, McFall AM, Kumar MS, Saravanan S, Balakrishnan $\mathrm{P}_{\text {, et }}$ al. Burden of liver disease among community-based people who inject drugs (PWID) in Chennai, India. PLoS One 2016;11:e0147879. doi: $10.1371 /$ journal.pone.0147879.

[96] Ray Saraswati L, Sarna A, Sebastian MP, Sharma V, Madan I, Thior I, et al. HIV, Hepatitis B and C among people who inject drugs: high prevalence of HIV and Hepatitis C RNA positive infections observed in Delhi, India. BMC Public Health 2015;15:726. doi: 10.1186/s12889-015-2003-z.

[97] Chalana H, Singh H, Sachdeva JK, Sharma S. Seroprevalence of human immunodeficiency virus, hepatitis B surface antigen, and hepatitis $C$ in substance dependents admitted in a tertiary hospital at Amritsar, India. Asian J Psychiatr 2013;6:552-555. doi: 10.1016/j.ajp.2013.08.064.

[98] Datta S, Banerjee A, Chandra PK, Mahapatra PK, Chakrabarti S, Chakravarty R. Drug trafficking routes and hepatitis $B$ in injection drug users, Manipur, India. Emerg Infect Dis 2006;12:1954-1957. doi: 10.3201/ eid1212.060425.

[99] Murhekar MV, Zodpey SP. Hepatitis B virus infection among Indian tribes: need for vaccination program. Indian J Gastroenterol 2005;24:269-270.

[100] Arankalle VA, Murhekar KM, Gandhe SS, Murhekar MV, Ramdasi AY, Padbidri VS, et al. Hepatitis B virus: predominance of genotype $D$ in primitive tribes of the Andaman and Nicobar islands, India (1989-1999). J Gen Virol 2003; 84:1915-1920. doi: 10.1099/vir.0.18943-0.

[101] Sibia P, Mohi MK, Kumar A. Seroprevalence of hepatitis B infection among pregnant women in one of the institute of Northern India. J Clin Diagn Res 2016;10:QC08-QC09. doi: 10.7860/JCDR/2016/20614.8299.

[102] Pande C, Sarin SK, Patra S, Bhutia K, Mishra SK, Pahuja S, et al. Prevalence, risk factors and virological profile of chronic hepatitis B virus infection in pregnant women in India. J Med Virol 2011;83:962-967. doi: 10.1002/ jmv.22017.

[103] Dwivedi M, Misra SP, Misra V, Pandey A, Pant S, Singh R, et al. Seroprevalence of hepatitis $B$ infection during pregnancy and risk of perinatal transmission. Indian J Gastroenterol 2011;30:66-71. doi: 10.1007/s12664011-0083-y.

[104] Solanke D, Rathi C, Pandey V, Patil M, Phadke A, Sawant P. Etiology, clinical profile, and outcome of liver disease in pregnancy with predictors of maternal mortality: A prospective study from Western India. Indian J Gastroenterol 2016;35:450-458. doi: 10.1007/s12664-016-0704-6.

[105] Terrault NA, Bzowej NH, Chang KM, Hwang JP, Jonas MM, Murad MH, et al. AASLD guidelines for treatment of chronic hepatitis B. Hepatology 2016; 63:261-283. doi: 10.1002/hep.28156.

[106] Sarin SK, Kumar M, Lau GK, Abbas Z, Chan HL, Chen CJ, et al. Asian-Pacific clinical practice guidelines on the management of hepatitis B: a 2015 update. Hepatol Int 2016;10:1-98. doi: 10.1007/s12072-015-9675-4.

[107] European Association For The Study Of The Liver. EASL. clinical practice guidelines: Management of chronic hepatitis B virus infection. J Hepatol 2012;57:167-185. doi: 10.1016/j.jhep.2012.02.010.

[108] Marfatia S, Gupta K, Mukherjee A, Mattoo V. Direct medical cost associated with the diagnosis and treatment of patients with chronic hepatitis- $B$ in three large metropolitan cities in India - a pilot study. Value Health 2015; 18:A581-A582. doi: 10.1016/j.jval.2015.09.1945.

[109] Amarapurkar DN, Madan K, Kapoor D. Management of Chronic Hepatitis B Infection in India. J Assoc Physicians India 2015;63:43-52.

[110] Panda C. Telbivudine plus tenofovir in combination therapy in patients with chronic hepatitis B infection-an Indian experience. J Assoc Physicians India 2013;61:785-788.

[111] Kumar M, Sarin SK. Systematic review: combination therapies for treatment-naïve chronic hepatitis B. Aliment Pharmacol Ther 2008;27:11871209. doi: 10.1111/j.1365-2036.2008.03695.x.

[112] Sarin SK, Guptan RC, Thakur V, Malhotra S, Malhotra V, Banerjee K, et al. Efficacy of low-dose alpha interferon therapy in HBV-related chronic liver disease in Asian Indians: a randomized controlled trial. J Hepatol 1996;24: 391-396. doi: 10.1016/S0168-8278(96)80158-9.

[113] Guptan RC, Thakur V, Malhotra V, Sarin SK. Low-dose recombinant interferon therapy in anti-HBe-positive chronic hepatitis B in Asian Indians. J Gastroenterol Hepatol 1998;13:675-679. doi: 10.1111/j.1440-1746. 1998.tb00712.x.

[114] Mazumder DG, Chaudhuri S, Konar A, Santra A, Pal B, Sarkar S. Response to low-dose interferon in chronic liver disease due to hepatitis $B$ virus infection. Indian J Gastroenterol 1998;17:97-99.

[115] Guptan RC, Thakur V, Raina V, Sarin SK. Alpha-interferon therapy in chronic hepatitis due to active dual infection with hepatitis $B$ and $C$ viruses. J Gastroenterol Hepatol 1999;14:893-898. doi: 10.1046/j.1440-1746.1999. 01952.x.

[116] Chowdhury A, Shah S, Babu S, Rai RR, Prasad VG, Rao R, et al. Safety and efficacy of an indigenous human recombinant interferon alpha $2 \mathrm{~b}$ (Shanferon) in patients with chronic hepatitis B. Trop Gastroenterol 2005; 26:70-72.

[117] Sarin SK, Kumar M, Kumar R, Kazim SN, Guptan RC, Sakhuja P, et al. Higher efficacy of sequential therapy with interferon-alpha and lamivudine combination compared to lamivudine monotherapy in $\mathrm{HBeAg}$ positive chronic hepatitis B patients. Am J Gastroenterol 2005;100:2463-2471. doi: 10. 1111/j.1572-0241.2005.00247.x.

[118] Ray G, Mondal S. Treatment of e+ chronic hepatitis B with Peginterferon alpha $2 \mathrm{~b}-$ an open label study from eastern India. J Gastroenterol Hepatol 2010;25:A89.

[119] Amarapurkar DN, Patel ND. Combination of Peginterferon alpha-2b (12 $\mathrm{kDa})$ and Lamivudine in difficult-to-treat chronic hepatitis B- an Indian experience. Ann Hepatol 2005;4:56-59.

[120] Sarin SK, Kumar M, Hissar S, Sharma BC. Combination of pegylated interferon and lamivudine for patients with chronic hepatitis B who have failed treatment. Hepatobiliary Pancreat Dis Int 2006;5:374-380.

[121] Sarin SK, Sood A, Kumar M, Arora A, Amrapurkar D, Sharma BC, et al. Effect of lowering HBV DNA levels by initial antiviral therapy before adding immunomodulator on treatment of chronic hepatitis B. Am J Gastroenterol 2007;102:96-104. doi: 10.1111/j.1572-0241.2006.01006.x.

[122] Aggarwal R, Ghoshal UC, Naik SR. Treatment of chronic hepatitis B with interferon-alpha: cost-effectiveness in developing countries. Natl Med J India $2002 ; 15: 320-327$.

[123] Ismail AM, Samuel P, Ramachandran J, Eapen CE, Kannangai R, Abraham P. Lamivudine monotherapy in chronic hepatitis $B$ patients from the Indian 
subcontinent: antiviral resistance mutations and predictive factors of treatment response. Mol Diagn Ther 2014;18:63-71. doi: 10.1007/s40291013-0054-3.

[124] Alexander G, Baba CS, Chetri K, Negi TS, Choudhuri G. High rates of early $\mathrm{HBeAg}$ seroconversion and relapse in Indian patients of chronic hepatitis $\mathrm{B}$ treated with Lamivudine: results of an open labeled trial. BMC Gastroenterol 2005;5:29. doi: 10.1186/1471-230X-5-29.

[125] Sarin SK, Sandhu BS, Sharma BC, Jain M, Singh J, Malhotra V. Beneficial effects of 'lamivudine pulse' therapy in HBeAg-positive patients with normal ALT*. J Viral Hepat 2004;11:552-558. doi: 10.1111/j.1365-2893.2004. 00542.x.

[126] Ismail AM, Ramachandran J, Kannangai R, Abraham P. Antiviral efficacy of adefovir dipivoxil in the treatment of chronic hepatitis B subjects from Indian subcontinent. Indian J Med Microbiol 2014;32:60-63. doi: 10. 4103/0255-0857.124312.

[127] Pradeep Kumar S, Medhi S, Asim M, Das BC, Gondal R, Kar P. Evaluation of adefovir \& lamivudine in chronic hepatitis B: correlation with HBV viral kinetic, hepatic-necro inflammation \& fibrosis. Indian J Med Res 2011; 133:50-56.

[128] Srivastava M, Singh N, Dixit VK, Nath G, Jain AK. Comparative evaluation of long-term monotherapies \& combination therapies in patients with chronic hepatitis B: A pilot study. Indian J Med Res 2016;144:424-432. doi: 10. 4103/0971-5916.198674.

[129] Wakil SM, Kazim SN, Khan LA, Raisuddin S, Parvez MK, Guptan RC, et al. Prevalence and profile of mutations associated with lamivudine therapy in Indian patients with chronic hepatitis $B$ in the surface and polymerase genes of hepatitis B virus. J Med Virol 2002;68:311-318. doi: 10.1002/ jmv.10205.

[130] Singla B, Chakraborti A, Sharma BK, Kapil S, Chawla YK, Arora SK, et al. Hepatitis B virus reverse transcriptase mutations in treatment Naïve chronic hepatitis B patients. J Med Virol 2013;85:1155-1162. doi: 10. $1002 / j m v .23608$.

[131] Kazim SN, Chauhan R, Das BC, Sarin SK. Association of core promoter mutations with viral breakthrough in chronic hepatitis $B$ patients on longterm lamivudine therapy. J Gastroenterol Hepatol 2006;21:1525-1532. doi: $10.1111 / j .1440-1746.2006 .04513 . x$

[132] Kazim SN, Sarin SK, Sharma BC, Khan LA, Hasnain SE. Characterization of naturally occurring and Lamivudine-induced surface gene mutants of hepatitis $B$ virus in patients with chronic hepatitis B in India. Intervirology 2006;49:152-160. doi: 10.1159/000089376.

[133] Jayakumar R, Joshi YK, Singh S. Laboratory evaluation of three regimens of treatment of chronic hepatitis $B$ : tenofovir, entecavir and combination of lamivudine and adefovir. J Lab Physicians 2012;4:10-16. doi: 10.4103/ 0974-2727.98664.

[134] Ray G. 5-year efficacy of entecavir in Indian patients with chronic hepatitis B. Indian J Gastroenterol 2016;35:190-194. doi: 10.1007/s12664-0160664-x.

[135] Patra UC. An open label prospective observational study to evaluate the efficacy of entecavir in $\mathrm{HBeAg}$ positive treatment naïve chronic hepatitis B patients in a tertiary care center in eastern India. Trop Gastroenterol 2011; 32:314-316.

[136] Ismail AM, Sharma OP, Kumar MS, Eapen CE, Kannangai R, Abraham P. Virological response and antiviral resistance mutations in chronic hepatitis $B$ subjects experiencing entecavir therapy: an Indian subcontinent perspective. Antiviral Res 2013;98:209-216. doi: 10.1016/j.antiviral.2013. 02.012.

[137] Goyal SK, Dixit VK, Shukla SK, Ghosh J, Behera M, Tripathi M, et al. Prolonged use of tenofovir and entecavir in hepatitis $B$ virus-related cirrhosis. Indian J Gastroenterol 2015;34:286-291. doi: 10.1007/s12664-0150576-1.
[138] Singla B, Bhattacharyya R, Chakraborti A, Sharma BK, Kapil S, Chawla YK, et al. Response to potent anti-HBV agents in chronic hepatitis B and combined effect of HBV reverse transcriptase mutations. Gene 2015;567: 22-30. doi: 10.1016/j.gene.2015.04.060.

[139] Srivastava M, Rungta S, Dixit VK, Shukla SK, Singh TB, Jain AK. Predictors of survival in hepatitis $B$ virus related decompensated cirrhosis on tenofovir therapy: an Indian perspective. Antiviral Res 2013;100:300-305. doi: 10 . 1016/j.antiviral.2013.08.020.

[140] Singh AK, Sharma MK, Hissar SS, Gupta E, Sarin SK. Relevance of hepatitis B surface antigen levels in patients with chronic hepatitis $B$ during 5 year of tenofovir treatment. J Viral Hepat 2014;21:439-446. doi: 10.1111/jvh. 12149.

[141] Amarapurkar DN, Patel N. Increased eGFR with telbivudine in combination therapy of chronic hepatitis B infection. Indian J Gastroenterol 2014;33: 89-91. doi: 10.1007/s12664-013-0325-2.

[142] Kapoor D, Guptan RC, Wakil SM, Kazim SN, Kaul R, Agarwal SR, et al. Beneficial effects of lamivudine in hepatitis $B$ virus-related decompensated cirrhosis. J Hepatol 2000;33:308-312. doi: 10.1016/S0168-8278(00) 80372-4.

[143] Bedre RH, Raj U, Misra SP, Varadwaj PK. Antiviral therapy with nucleotide/nucleoside analogues in chronic hepatitis B: A meta-analysis of prospective randomized trials. Indian J Gastroenterol 2016;35:75-82. doi: 10.1007/s12664-016-0632-5.

[144] Maiwall R, Kumar M. Prevention and treatment of recurrent hepatitis $B$ after liver transplantation. J Clin Transl Hepatol 2016;4:54-65. doi: 10.14218/ JCTH.2015.00041.

[145] Wadhawan M, Gupta S, Goyal N, Taneja S, Kumar A. Living related liver transplantation for hepatitis B-related liver disease without hepatitis B immune globulin prophylaxis. Liver Transpl 2013;19:1030-1035. doi: 10. $1002 /$ It.23692.

[146] Varghese J, Sachan D, Reddy MS, Cherian T, Jothimani D, Venugopal K, et al. Hepatitis B immunoglobulin prophylaxis after liver transplantation: experience in a tertiary transplant centre. J Clin Exp Hepatol 2014;4: 209-213. doi: 10.1016/j.jceh.2014.07.007.

[147] Garg H, Sarin SK, Kumar M, Garg V, Sharma BC, Kumar A. Tenofovir improves the outcome in patients with spontaneous reactivation of hepatitis B presenting as acute-on-chronic liver failure. Hepatology 2011;53: 774-780. doi: 10.1002/hep.24109.

[148] Aggarwal R, Naik SR. Cost efficacy evaluation of inclusion of hepatitis-B vaccine in expanded programme of immunization. In: Sarin SK, Singhal AK, ed. Hepatitis B in India. CBS Publishers and Distributors, 1996: 206-216.

[149] Operational guidelines for hepatitis B vaccine introduction in the Universal Immunisation Programme, Ministry of Health and Family Welfare. Government of India 2011.

[150] Aggarwal R, Babu J], Hemalatha R, Reddy AV, Sharma D, Kumar T. Effect of inclusion of hepatitis $B$ vaccine in childhood immunization program in India: a retrospective cohort study. Indian Pediatr 2014;51:875-879. doi: 10. 1007/s13312-014-0520-y.

[151] Palaniappan K, Borkar VV, Safwan M, Vij M, Govil S, Shanmugam N, et al. Pediatric hepatocellular carcinoma in a developing country: Is the etiology changing? Pediatr Transplant 2016;20:898-903. doi: 10.1111/petr.12754.

[152] Bhattacharya H, Bhattacharya D, Ghosal SR, Roy S, Sugunan AP. Status of hepatitis B infection - a decade after hepatitis B vaccination of susceptible Nicobarese, an indigenous tribe of Andaman \& Nicobar (A\&N) islands with high hepatitis B endemicity. Indian J Med Res 2015;141:653-661.

[153] Lahariya C, Subramanya BP, Sosler S. An assessment of hepatitis B vaccine introduction in India: Lessons for roll out and scale up of new vaccines in immunization programs. Indian J Public Health 2013;57:8-14. doi: 10. 4103/0019-557X.111357. 